\title{
THE FINANCIAL CRISIS OF 2009 - HAVE REORGANIZATION PROCEEDINGS IN EMERgING MARKETS GONE BANKRUPT? ISRAEL AS A CASE STUDY
}

\author{
David Hahn*
}

\section{INTRODUCTION}

Much like ripples from a pebble radiating to distant shores, the 2007 meltdown of the U.S. market of subprime loans for home ownership ${ }^{1}$ and the subsequent collapse of the real estate market ${ }^{2}$ eventually transformed into a nationwide financial crisis in 2008 and contaminated other economies around the world. ${ }^{3}$ The intertwined investments of private investors and institutional investors, such as financial institutions and public and private funds from all over the world in the U.S. financial

* Senior Lecturer, Bar-Ilan University School of Law, Israel. J.S.D. NYU School of Law. I am grateful to Gideon Parchomovsky, Assaf Hamdani, Steve Lubben, Harry Rajak, and Janis Sarra for helpful comments on earlier versions of this paper.

1. See, e.g., How to Sort Out America's Mortgage Crisis, The ECONOMIST, Feb. 28, 2008, available

http://www.economist.com/finance/displaystory.cfm?story_id=E1_TDSGGQPN (describing the increasing number of foreclosures in America). For the wide spread of subprime loans in the U.S. population, see Bob Tedeschi, Subprime Loans' Wide Reach, N.Y. TIMES, Aug. 3, 2008, at RE10 (finding that subprime loans affected low-income and minority households but also upper-income borrowers).

2. But see Stan Liebowitz, New Evidence on the Foreclosure Crisis: Zero Money Down, Not Subprime Loans Led to the Mortgage Meltdown, Wall St. J., July 3, 2009, at A13 (showing that since Q4 of $200651 \%$ of foreclosures are on prime loans and that the foreclosure rate on prime loans has risen by $488 \%$ while the foreclosure on subprime loans has risen by only $200 \%$, and arguing accordingly that the single most important factor in the mortgage foreclosure crisis is the negative equity that homeowners have in their houses).

3. Wall Street's doomsday was Monday, September 15, 2008, when Lehman Brothers announced that it would file for Chapter 11 protection and Bank of America announced that it would buy the heavily indebted Merrill Lynch. See, e.g., David Ellis, Changes Rock Wall Street, CNN, Sept. 15, 2009, http://edition.cnn.com/2008/US/09/15/banks.bigchanges/index.html (reporting that the failures of Lehman and Merrill Lynch will "profoundly alter the American financial landscape”). 
market transported the crisis on to foreign markets in Europe, ${ }^{4}$ Asia, ${ }^{5}$ and the Middle East. ${ }^{6}$ The economies that have been hit include both well developed economies and rapidly emerging markets. Emerging markets around the world have been transforming gradually from prototypically concentrated banking markets to more balanced markets, relying more than before on corporate bonds issuing. ${ }^{7}$ Thus, the current global economic crisis is a novel challenge for such markets. Economies hit by the crisis must address broadly the rights of bondholders as the issuing firms are facing financial distress.

Israel is a classic example of a rapidly growing emerging market, which has recently joined as a member the Organisation for Economic Cooperation and Development (OECD). ${ }^{8}$ As such, the manner in which Israel handled the financial crisis can illustrate how the private sector and the government in emerging markets can overcome the global crisis through the utilization of traditional and novel mechanisms. Indeed, unlike the Biblical tenth plague, the plague of the current global economic crisis has not passed over Israel. ${ }^{9}$ The crisis has caught Israel at a crossroads. In the last decade, Israel's economy has gradually changed from a concentrated debt market towards a more balanced market where issues of corporate bonds have become a practical and friendly alternative to bank lending for

4. See, e.g., Erik Berglöf, One Year Into the Credit Crunch: What Have We Learned?, European Bank for Reconstruction \& Development, Sept. 19, 2008, http://www.ebrd.com/new/stories/2008/080919.htm (stating that countries with the most ties to international financial markets like Kazakhstan will be most affected).

5. See, e.g., Asian Markets Tumble after Lehman Collapse, THE Times of India, Sept. 16, 2008, http://timesofindia.indiatimes.com/articleshow/msid-3488073,prtpage-1.cms (noting that markets in Hong Kong and Tokyo experienced the largest one-day loss since 9/11).

6. See, e.g., Prince El Hassan bin Talal, The Global Financial Crisis and the Middle East, ALJAZEERA MAGAZINE, Oct. 2008, http://www.aljazeera.com/news/articles/39/The_global_financial_crisis_and_the_Middle_E ast.html (finding that even areas in the Middle East not integrated into the global capital markets will be affected by the global financial crisis).

7. For a comprehensive account of the differences between concentrated and diffuse debt markets, see John Armour et al., Corporate Ownership Structure and the Evolution of Bankruptcy Law: Lessons from the United Kingdom, 55 VAND. L. REV. 1699 (2002).

8. See OECD, Accession: Estonia, Israel and Slovenia invited to join OECD, http://www.oecd.org/document/57/0,3343,en_2649_201185_45159737_1_1_1_1,00.html (May 10, 2010). For a statistical summary of Israel's economy, see OECD, Country Statistical Profiles 2009: Israel, http://stats.oecd.org/viewhtml.aspx?queryname $=18187 \& q u e r y t y p e=v i e w \& l a n g=e n \quad$ (last visited Mar. 1, 2010).

9. See Exodus 12:12-13 (New International Version) (“On that same night I will pass through Egypt and strike down every firstborn — both men and animals-and I will bring judgment on all the gods of Egypt. I am the LORD. The blood will be a sign for you on the houses where you are; and when I see the blood, I will pass over you. No destructive plague will touch you when I strike Egypt.”). 
raising corporate debt. ${ }^{10}$

Diffuse bond holdings by the public as well as bulk holdings by institutional investors introduced new players to the traditional arena of corporate creditors and changed its landscape. The prototypical group of creditors of a corporation in a concentrated debt environment is traditionally comprised of banks, commercial suppliers and service providers, tax authorities, and employees. ${ }^{11}$ The change in Israel's credit market added an important new actor to the mix - the bondholders.

Most series of bonds that have been issued by Israeli firms are unsecured. Many investors invested in bonds with little regard to the legal rights attached to the bonds and the investment risks associated therewith. Protecting the bondholders' rights upon a financial distress of the borrowing firm is unfamiliar territory for the Israeli investors. ${ }^{12}$ Thus, in the recent crisis, the institutional investors and other bondholders were debating among themselves and with the issuing firms (i.e., the borrowers) what could be done in order to minimize their losses and save their investments in the distressed firms.

The fear of massive defaults on commercial bonds has drawn the full attention of the government as well. Given that institutional investors, who aggregate the public's long term savings, have heavily invested in the bonds market, the government became concerned about the public's money. In responding to this concern, the government explored and publicly discussed various alternatives for its active intervention in the bonds crisis. As will be elaborated in this paper, these plans included government guarantees, insurance, the founding of credit funds, and more. $^{13}$

This paper highlights an available mechanism that has been sparsely used in the current crisis - formal reorganization proceedings under bankruptcy law. Reorganization proceedings are by no means the exclusive or necessarily the optimal mechanism for handling a financial

10. On the importance of corporate bonds as a financing alternative to bank lending, see Meir Sokoler, Senior Director In Charge of Monetary Affairs, Bank of Israel, The Importance of a Well Developed Bonds Market: An Israeli Perspective, Jan. 28, 2002, http://www.bankisrael.gov.il/deptdata/neumim/neum085e.htm.

11. This is particularly typical in the financing of SMEs, even in developed economies. Berger and Udell find that in the U.S. approximately $70 \%$ of the financing of small businesses comes from the principal equity holder, financial institutions (primarily commercial banks) and trade creditors. Allen N. Berger \& Gregory F. Udell, The Economics of Small Business Finance: The Roles of Private Equity and Debt Markets in the Financial Growth Cycle, 22 J. BANK. \& Fin. 613 (1998).

12. For the relative disadvantages of dispersed creditors in reacting to a management's initiative for a restructuring plan, see Arturo Bris \& Ivo Welch, The Optimal Concentration of Creditors, 60 J. FIN. 2193 (2005).

13. See Part III.B infra (discussing financial initiatives proposed by several governmental agencies in an effort to assist in dealing with the recent crisis). 
crisis. $^{14}$ These proceedings are, nonetheless, a useful mechanism. This paper compares the relative advantages of formal reorganization proceedings and governmental intervention and outlines the underlying obstacles that currently impede the use of bankruptcy even when it is an adequate channel for handling the bonds crisis.

Moreover, this paper criticizes the current legal state of the domestic reorganization law and calls for certain revisions that would likely facilitate the use of formal reorganization as a viable and efficient mechanism for handling bondholders' rights upon the financial distress of a firm. Additionally, this paper argues that alongside any legal reform, the erroneous cultural perception of reorganization proceedings as an event indicating failure and as instigating a problem for the creditors must give way to a more balanced and businesswise understanding that such proceedings merely reflect a preexisting economic problem and that these proceedings may actually produce an opportunity for rescue where "conventional" treatments fail.

This paper is organized as follows. Part II outlines the effects of the global crisis on the domestic Israeli market. It will show particularly how the bonds market has declined as a result of the crisis, cutting the value of long term savings of the general public and turning the crisis into a national concern. Part III then describes the various proposed and advanced initiatives to tackle the bonds crisis, both by the private sector and by the government. In the private sector, the controlling shareholders of the issuing firms began negotiating haircuts of the bonds and repurchasing the bonds at a discount on the secondary market. On its end, the government proposed several financing channels to support the market and drafted a bill that would facilitate out-of-court workouts.

Part IV of the article turns the focus to bankruptcy law. It shows empirically that the parties hardly use bankruptcy proceedings for resolving the firms' financial distress. It then analyzes the reasons for this seldom use of bankruptcy, which includes legal impediments and psychologicalcultural barriers. In Part V, the paper discusses the relative advantages of a governmental intervention in favor of the private sector on one hand and the advantages of a case-by-case bankruptcy resolution for financial distress. This discussion concludes that no approach clearly outweighs the alternative.

Given the importance of the alternative of formal bankruptcy, Part VI then calls for a change in the cultural attitude and the adoption of formal

14. See Edward R. Morrison, Bargaining Around Bankruptcy: Small Business Workouts and State Law (Colum. L. \& Econ, Working Paper No. 320), available at http://papers.ssrn.com/sol3/papers.cfm?abstract_id=1065543 (showing that the vast majority of small businesses in the U.S. use non-bankruptcy procedures to reorganize or liquidate). 
reorganization as a legitimate and useful means for resolving a firm's financial distress. To encourage this change of heart in the business sector, I propose several legal revisions including a partial adoption of a debtor-inpossession (DIP) controlled reorganization regime, the carving of floating charges in favor of unsecured creditors, facilitating the continuance of executory contracts and the enactment of a cramdown provision for confirming a reorganization plan.

Part VII offers possible implications of the Israeli case study for the U.S. markets. Joining the commentators who have advocated the use of formal bankruptcy in lieu of a general government bailout, the precedent of Israel's corporate bonds crisis shows that government non-intervention indeed drives the private sector to negotiate independent resolutions and bear the costs of its poor investment decisions. Given the superiority of U.S. bankruptcy law and its hospitable atmosphere, such negotiations are expected to prove even more successful in the U.S. This paper concludes with a call for using the crisis as a catalyst for reforming Israel's reorganization law and transforming it into an attractive option for saving viable businesses.

\section{THE GLOBAL CRISIS AND THE DOMESTIC MARKET}

\section{A. Israel's Changing Capital Market}

Israel's three largest banks, Bank Leumi, Bank Hapoalim and Bank Discount, have suffered a significant loss in 2008 as a result of their investments in structured investment vehicles in the U.S. ${ }^{15}$ Fortunately, and thanks to early intervention and action by the Bank of Israel, ${ }^{16}$ these losses were far from threatening the overall financial stability of these banks. ${ }^{17}$ Nonetheless, the operating loss has trimmed the banks' net worth

15. See, e.g., Sharon Shpurer, U.S. Subprime Mortgage Crisis Hits Discount and Leumi Too, HAARETZ, July 14, 2008, http://www.haaretz.co.il/hasen/spages/1001364.html (noting that Discount was down 33\% and Leumi down 17\% from the start of the year); Sharon Shpurer \& Rotem Starkman, Relief and Red Ink at Bank Hapoalim, HAARETZ, May 23, 2008, http://www.haaretz.co.il/hasen/spages/985892.html (discussing how Bank Hapoalim finally sold its portfolio of mortgage-based securities after losing about $\$ 1.3$ billion on its adventures in the U.S. market for loans to homebuyers of dubious creditworthiness); Ram Dagan, What Bank Hapoalim Forgot to Mention, HAARETZ, Dec. 12, 2007, http://www.haaretz.com/hasen/spages/933208.html (revealing that Bank Hapoalim did not mention that it had $\$ 1.6$ billion directly exposed to international credit markets).

16. Press Release, Bank of Israel Office of the Spokesperson and Economic Information, The Effect of Global Processes on Israel's Banking System (Dec. 12, 2007), available at http://www.bankisrael.gov.il/press/eng/071209/071209e.htm.

17. Letter from Mr. Rony Hizkiyahu, Supervisor of Banks, The Research Unit, Bank of Israel (2008), available at http://www.bankisrael.gov.il/deptdata/pikuah/skira07/ch-t_e.pdf 
to a level that, until recently, made it extremely difficult for them to comply with the central bank's requirement that they meet the capital adequacy standards of Basel II by the end of 2009. ${ }^{18}$ As a result, by the end of 2008, the availability of credit to the business sector had shrunk significantly. ${ }^{19}$

Since the rise of Israel's high-tech corporations, the global activity and investments of large Israeli conglomerates and financial institutions, and the country's general subsequent economic growth, the operation costs of the fast growing Israeli businesses increased consistently. As a result, new channels of financing, such as venture capital, were utilized alongside the banking system. ${ }^{20}$ One of the most significant developments in Israel's capital market in the past decade was the shift to raising capital through the issuing of corporate bonds. While the capital market has been active for many years, the main vehicle for raising capital was traditionally corporate stock. Until the new millennium, corporate bonds offerings were relatively negligible. $^{21}$ In recent years, however, corporations have discovered the promise of raising capital through the issuing of bonds. Bonds issuing quickly became the main channel of raising capital in the market in the current decade, surpassing the amount of capital raised through stock offerings. The year 2007 marked the peak in bonds issuing, as over \$20 billion U.S. dollars $(\$ 20,000,000,000)$ were raised, before the eventual sharp decline of 2008-2009. ${ }^{22}$ As of March 2009, there were 638 listed

("The shocks experienced by the global and domestic financial markets in late 2007 did not overlook Israel's banking system, mainly due to the banks' holdings of asset-backed securities. Nevertheless, their effect was relatively subdued and did not undermine system stability. The events did, however, suggest that the foreseen global economic slowdown is likely to affect Israel, too.”).

18. As of late, Bank Hapoalim was successful in raising fresh capital, and even enjoyed oversubscription. As a result thereof the bank has met the requisite adequacy of capital standard. Adi Ben-Israel \& Erez Wohlberg, Bank Ha-Poalim Raised 1.7 Billion Shekels, June 30, 2009, http://www.globes.co.il/news/article.aspx?did=1000476143\&fid=585 (Hebrew)

19. Ms. Rakefet Rosek-Aminah, Head of the Business Division of Bank Leumi, stated however that the credit crunch is specifically in non-bank credit (i.e. the decline of the bonds market), while the banks are stable, adequately capitalized and offering credit to their business customers at the same level as in the past. Globes Capital Market Summit, May 13, 2009, http://www.globes.co.il/news/article.aspx?did=1000449533\&fid=2 (Hebrew).

20. In the second quarter of 2009 , Israeli venture capital funds accounted for $40 \%$ of the total amounts invested in the Israeli high-tech industry. AltAssets, Israel High-Tech Companies Raised $\$ 279 m$ in Venture Capital in Q2 2009, July 17, 2009, http://www.altassets.com/private-equity-news/by-region/middle-eastisrael/israel/article/nz16289.html.

21. In contrast to the private sector, the government made use of the capital market to offer government bonds for financing many years earlier. Asher A. Blass \& Oved Yosha, Reform in the Israeli Financial System and the Flow of Funds of Publicly Traded Manufacturing Firms, in THE ISRAELI ECONOMY, 1985-1998: FROM GOVERNMENT INTERVENTION TO MARKET ECONOMICS 189, 191 tbl.6.1 (Avi Ben-Bassat ed. 2002).

22. Tel-Aviv Stock Exchange, Corporate Fact Sheet (February 2010), 
corporations in the Tel-Aviv Stock Market, 546 issued and outstanding series of bonds, and the overall market capitalization was comprised of $\$ 140$ billion U.S. dollars worth of equity instruments and $\$ 160$ billion U.S. dollars worth of bonds. ${ }^{23}$

The widespread public debt offerings of the new millennium slowly changed the landscape of the domestic financial market in several aspects. First, with respect to its public corporations, Israel is gradually shifting from a typical concentrated banking market to a more balanced market, where the holding of corporate debt is split between the banks and bondholders. ${ }^{24}$ Secondly, a large portion of the corporate bonds issued has been purchased by institutional investors, such as pension funds, mutual funds, and insurance companies. ${ }^{25}$ As a result, negotiations between an ailing firm and its creditors now involve these investors alongside the banks. The number of key players in any arrangement that the firm may wish to orchestrate has risen and reaching a consensual compromise has become more complicated. ${ }^{26}$ Third, the magnitude of debt and the debt to equity ratio that firms undertake are significantly higher than in the past. Since firms have been able to sidestep the banks and offer unsecured debt to the public, the relatively rigid banking limitations on a firm's borrowing

http://www.tase.co.il/TASEEng/AboutTASE/Overview/CorporateFactSheet (last visited March 9, 2010).

23. Id.

24. The market share of Israel's commercial banks in the overall outstanding credit to the private sector (consumers and businesses combined) has dropped from $79.7 \%$ in 2003 to $67.12 \%$ in 2008. More specifically, the banks' share in the outstanding credit to commercial businesses has dropped from $71.91 \%$ in 2003 to $55.28 \%$ in 2008 . Bank of Israel, Outstanding Credit in the Economy, http://www.bankisrael.gov.il/deptdata/stability/indic/t03h.xls (last visited May 12, 2009) (Hebrew).

25. As of the end of 2008, the general public held $50.9 \%$ of all outstanding corporate bonds, the foreign investors held $0.3 \%$, and institutional investors held $48.8 \%$. The institutional investors' holdings were as follows: mutual funds-21.9\% (of the overall bonds); insurance companies-10.7\%; pension funds-7.5\%; trust funds-6.1\%; and banks-2.5\%. Bank of Israel, The Division of Holdings of Traded Non-Governmental Bonds 2005-2009, http://www.bankisrael.gov.il/deptdata/monetar/assets/tnc12_h.xls (last visited May 12, 2009) (Hebrew). Corporate bonds comprise approximately $32 \%$ of the institutional investors' overall portfolio, with bonds rated AA- or higher accounting for 78.3\% of the overall bonds held by these investors. MinISTRY OF FINANCE, CAPITAL MARKETS, INSURANCE AND SAVINGS DIVISION, INCREASING THE INVOLVEMENT OF Institutional InVESTORS IN DEBT ARRANGEMENTS AND TAKING ACTIONS OF COLLECTION (Feb. 2009), http://www.finance.gov.il/hon/2001/general/memos/mosdyim2009.pps\#3 (Hebrew).

26. Urlich Hege, Workouts, Court-Supervised Reorganization and the Choice between Private and Public Debt, 9 J. CoRP. Fin. 233 (2003). Cf. Elazar Berkovitch \& Ronen Israel, Optimal Bankruptcy Laws Across Financial Systems, 12 REV. FIn. STUd. 347 (1999); Enrica Detragiache, Public Versus Private Borrowing: A Theory with Implications for Bankruptcy Reform, 3 J. FIn. INTERMED. 327 (1994). 
potential have been relaxed and overridden. ${ }^{27}$ Finally, due to the development of bonds issues, much of the corporate debt is not held throughout the term of the loan by the original investor but is being traded on the secondary market. This facilitates liquidity for the original investors-lenders and allows them to pass on the credit risks to speculative investors. It also facilitates a relatively simple exit for original lenders, who wish to fix their losses at a certain level and avoid any potential additional decline of their investments outside or inside formal insolvency proceedings.

\section{B. Importation of the Global Crisis}

\section{Real Estate Corporations}

The most significant direct effect of the global crisis on the Israeli market was the operation and investment losses suffered by the country's largest public conglomerates that manage large commercial real estate development projects around the globe. Israeli corporations act today across the globe, including leading economies as India and China in Asia, Eastern and Central Europe, and North America. A classic example of this foreign real estate activity is the 2007 launching of the Las Vegas Plaza Hotel grand project, undertaken as a joint venture by IDB and Delek, two of the largest non-bank conglomerates in Israel. ${ }^{28}$ In conjunction with broadening the scope of their real activity, these corporations have also diversified their financing sources. In addition to traditional financing by Israeli banks, part of the investments in foreign real estate was financed by foreign banks. Domestic banks in the target countries enjoy superiority in enforcing financial obligations, especially through foreclosure on the real estate to the extent it has been collateralized by the borrower corporation. Indeed, many bank loans, the purpose of which was the financing of such projects, were secured by the developing real estate on a non-recourse basis. ${ }^{29}$

The loss of value in foreign real estate investments contaminated

27. Shane A. Johnson, The Effect of Bank Debt on Optimal Capital Structure, 26 FIN. MAN. 47 (1997).

28. See Plaza Owners Elad Plan \$8 Billion Las Vegas Casino, ReUTERS, Nov. 13, 2007, http://www.reuters.com/article/idUSN1358343220071113 (describing plans to build a hotel, residences, shops, restaurants and a casino, originally expected to be completed in 2011).

29. Non-recourse financing is common for real estate development projects. JEFFREY Delmon, Project Finance, BOT Projects And Risk, 79-95 (Aspen Publishers 2005). 
domestic investments in the Israeli capital market as well. ${ }^{30}$ The real estate crisis in North America and Europe adversely affected the economic value of Israeli corporate bonds. Once the value of real estate in those economic markets depreciated and was marked down in the firms' financial statements, it no longer covered the non-recourse bank loans. The banks became undersecured and, consequently, no surplus remained for satisfying the unsecured claims of the bondholders. The firms' credit ratings declined and raising new capital to service current debt payments became overly expensive. Also, the general downturn in the foreign economies slowed down the sales and leases of completed projects and thus further constrained the Israeli firms' cash-flow. Thus, periodical interest payments on domestic bonds were exposed to a substantial risk of default. ${ }^{31}$ As a result, in 2008 the Tel-Bonds 20 and the Tel-Bonds 40 indices dropped 3\% and $22 \%$, respectively. ${ }^{32}$

In May 2009, the Israel Securities Authority (ISA) reviewed the payments listed corporations owed to their creditors for the first half of 2009. Of 258 corporations with due payments during the surveyed period, the ISA took a sample of 141 of the 258 corporations with payments due during the surveyed period. ${ }^{33}$ Of these 141 corporations, 114 corporations owed primarily non-bank debt (that is, bonds debt). ${ }^{34}$ The total debt payments due by the sampled corporations by the end of June 2009 totaled $\$ 3$ billion dollars, ${ }^{35}$ of which real estate corporations owed $\$ 1.25$ billion dollars (approximately $42 \%$ of the total sampled debt). ${ }^{36}$ The ISA estimated that about 0.3 billion dollars, or $11 \%$ of the total debt of the sampled corporations, would not be paid by the end of June 2009 due to the issuing firms' insolvency. ${ }^{37}$

The year 2009 may be just the first in a series of years where Israel's

30. As of the end of 2008, there were 141 real estate, construction and agricultural corporations listed on the TASE. Tel Aviv Stock Exchange, The Development of the Number of Listed Corporations, 2009, available at http://www.tase.co.il/NR/rdonlyres/BAOFA418-0993-4BB6-B67475C961A04F9E/0/Stat_106_2009.pdf (last visited May 20, 2009) (Hebrew).

31. The Israel Securities Authority (ISA) demanded as of late 2007 that all firms investing in and operating real estate projects in Europe and the USA must disclose in a special report the possible effect of the subprime crisis on their operations.

32. Tel Aviv Stock Exchange, 2008 Annual Report (Dec. 2008), available at http://www.tase.co.il/NR/rdonlyres/C701C5B1-6876-48FA-8E5A-

6F69DF77B96F/0/Research_2008_12_140291.pdf (last visited July 20, 2009) (Hebrew).

33. ISA, Economic Department, The 2007/2009 Credit Crisis, A Study for Assessing the Corporations' Ability to Meet their Obligations in the First Half of 20092 (2009), available at http://www.isa.gov.il/Download/IsaFile_3962.pdf (Hebrew).

34. Id. at 8.

35. Id. at 2 .

36. Id. at 3.

37. Id. at 5. 
capital market will face the challenge of financially distressed corporations satisfying their bonds payments. The aggregate payment of issued and outstanding bonds traded on the TASE due between 2010 and 2013 is $\$ 22.5$ billion dollars. ${ }^{38}$ Of this amount, approximately $\$ 5$ billion dollars, or $22.2 \%$, is due on bonds that, as of the end of April 2009, were traded on the market at a discount of $25 \%$ or more off of their par value. ${ }^{39}$ This calls into question the solvency of the issuing corporations. Although the bonds market recovered to some extent in July and August 2009, one should not overlook the severity of the crisis and its potential adverse effect on the entire non-bank credit market. ${ }^{40}$ Indeed, the announcement by AfricaIsrael, a real estate giant conglomerate, that it will not be able to meet its future bonds payments, may be just the first sign of a dim future. ${ }^{41}$

\section{Shrinkage of Export}

Real estate firms are by no means the sole business entities exposed to the global crisis. In the global investment atmosphere, some of Israel's largest banks invested significant amounts in U.S. SIVs and suffered severe losses during the second half of 2008, when Wall Street and the rest of the U.S. financial system collapsed. ${ }^{42}$ Moreover, even commercial and industrial firms who do not maintain operations and investments abroad suffered from the global crisis. Given the slowdown of the European and American economies and the decrease in demand for products and services, commercial exports from Israeli firms to these major markets correspondingly shrunk. ${ }^{43}$ The decline in sales has strangled the cash-flow

38. ISA, Economic Department, The 2007/2009 Credit Crisis, The Corporate Bonds Market - Expected Payments 3 (2009), available at http://www.isa.gov.il/Download/IsaFile_3961.pdf. (Hebrew).

39. Id. For payments due in any given quarter between 2009 and 2011, real estate corporations account for anywhere between $50 \%-70 \%$ of the bonds that have been traded at a discount of $25 \%$ or more off of their par value. Id. at 4.

40. See Globes Researches \& PriceWaterhouseCoopers, Debt \& Order-From Crisis to Arrangement? The Corporate Bonds Market--The Next Generation, 31 (July 2009), available at http://smile.globes.co.il/research/cbonds.pdf. (Hebrew) (stating that it is doubtful whether the non-bank credit market could be rehabilitated without first treating the distressed debts and developing mechanisms that will decrease the risk of a future recurrence of the crisis in the bonds market).

41. See AFI, Financial Statements, Quarterly Statement for the Period Ending on June 30, 2009, note 1B, available at http://maya.tase.co.il/bursa/report.asp?report_cd=469018. (Hebrew) (publicly announcing its financial distress and need for a creditors' arrangement).

42. See supra text accompanying note 15 (discussing how Israel's three largest banks, Bank Leumi, Bank Hapoalim and Bank Discount, suffered a significant loss in 2008 as a result of their investments in the U.S.).

43. Bank of Israel, Research Department, The Economic Developments between MayAugust 2008, 3 available at http://www.bankisrael.gov.il/develheb/develheb122/develheb.pdf. (Hebrew) (stating that the 
of these firms and impeded their ability to fulfill their debt obligations.

\section{Transformation into a Macro Crisis}

The wide scope of the bonds crisis transformed a seemingly isolated and micro crisis of certain distressed firms into a macro crisis that threatened the stability and integrity of the entire capital market. Too much money of too many investors was at stake. Institutional investors became a viable alternative to bank lending only in recent years. Should these investors suffer too large a loss in the crisis, it may effectively drive them out of the credit market and cause them to restructure their portfolios and concentrate on the stock market. As a result, the main achievements of the reform spearheaded by the Bachar Banking Reform Committee, including altering the supply of credit to businesses, creating a competitive credit environment and curtailing the banks' absolute control of this market, would be negated. ${ }^{44}$ Thus, maintaining the ex-bank credit market requires the enactment of safety measures to protect the institutional investors' investments.

Moreover, the institutional investors invest in the capital market with money raised from and managed on behalf of laymen who manage their long term savings through those institutions. Pension funds, mutual funds and insurance companies manage hundreds of billions of Israeli Shekels belonging to employees and individual entrepreneurs who save for their retirement. ${ }^{45}$ The government approved investment of these savings in the capital market in order to enhance the returns on these savings, on one hand, and inject fresh financing to the growing and demanding capital market, on the other. ${ }^{46}$ The great losses that the institutional investors were likely to suffer as a result of the corporate bonds crisis were the general population's lifelong savings. The belief was that the government would not allow such dramatic outcomes, which affect the foundations of the labor and capital basis of the country's economy, to unravel. The government, through the Ministry of Finance, indeed was not indifferent to the macro ramifications of the bonds' crisis. It searched for certain protective and stimulus measures to address the crisis and its negative impact. The exact form of intervention would be determined by the newly

continuation of economic crisis in the U.S. and its spillover into Europe increase the risk that the crisis will affect Israel as well).

44. For an outline of the Bachar Committee and its subsequent transpiring, see Bachar Reform, available at http://www.finance.gov.il/bachar/pdf/bachar_English.pdf.

45. The value of the total assets managed by the mutual funds alone, as of the end of 2008, was approximately \$54 billion dollars. MOF, Capital Markets, Insurance and Savings Division, Mutual Funds-2008 Annual Summary, available at http://147.237.72.127/kupot_gemel/kg_sikum_main.htm (Hebrew).

46. Bachar Committee, supra note 44. 
elected government following the general elections of February 2009. Nonetheless, even in the months preceding the induction of the new government, the public expected an imminent governmental response. Meanwhile, all parties involved became fixed in their positions and any initiatives to settle the crisis of any particular firm separately were delayed as long as the firm had not actually defaulted on a payment.

The names of the firms that suffered from cash distress, their size relative to Israel's economy, and the identity of their controlling shareholders is yet another factor that painted this crisis in a dramatic fashion. Among the firms whose bonds were traded in the second half of 2008 at significant discounts are some of the country's largest conglomerates, ${ }^{47}$ including ten corporations whose bonds are included in the blue chip Tel-Bond 20 index. $^{48}$ These giants are considered the backbone of Israel's economy and its bridges to the global market. Furthermore, the controlling shareholders of these conglomerates are the most powerful and influential persons in Israel, who enjoy close relationships with the politicians and regulators. Whether justified or not, their personal precarious positions in this crisis quickly became an independent public concern. Using their access to the government and the media, these tycoons publicly portrayed the financial crisis of their business groups as a larger general crisis of Israel's economy as a whole. ${ }^{49}$ Turning their personal business crises into a national one helped their cause and allowed them to lobby for a wide-range, government brokered solution that would save the corporations, and would also preserve their control and holdings in those business groups.

47. For a discussion of the financial distress of the real estate giant Africa-Israel, see Yuval Maoz, Africa-Israel Bonds Dropped 20\%; Delek Real Estate Dropped 11.1\% to a Discount of 38\%, HAARETZ, Oct. 2008, http://www.haaretz.co.il/hasite/pages/ShArtPE.jhtml?itemNo=1026053\&contrassID $=2 \& s u$ $b$ Contrass $I D=17 \& s b S u b C o n t r a s s I D=0$ (Hebrew); Michael Rochvarger, Can Leviev Repay NIS 23 Billion?, HAARETZ, Oct. http://www.haaretz.com/hasen/spages/1032847.html.

48. The most notable drops of market value of bonds in 2008 were those of AfricaIsrael (70\%), Gazit Globe (30\%) and Amot (15\%) - all real estate centered businesses. Other notable conglomerates whose bonds plunged were of IDB Development and Discount Investments (10\%). See TASE, supra note 32 (presenting drops in market value of bonds for the year 2008).

49. See, e.g., Elazar Levine, Akirov: Without a Bonds Arrangement Things will Turn Bad, News1, Apr. 1, 2009, http://www.news1.co.il/Archive/001-D-195944-00.html?tag=1827-55 (last visited July 20, 2009) (Hebrew) (citing the tycoon Alfred Akirov as stating that without a general bonds payment arrangement the economic situation will turn bad for all). 


\section{RESPONSE TO THE CRISIS}

\section{A. The Private Sector}

\section{Negotiating for Haircuts}

The imminent risk of default, coupled with the shortage of cash in the financial sector limits the firms' options. Successful negotiated settlements that would eventually result in refinancing of the corporate bonds depend on the ability of the firms to unify their bondholders and persuade them that this is their best option to eventually collect their claims. Haircuts of bonds, that is, relieving the corporate issuer from paying back a certain percentage of the bonds' par value, is an idea that was thrown into the public discourse, but was received critically by the investors. ${ }^{50}$ The general understanding was that such mitigations of the corporate debt are unfair and run afoul of the fundamental principles of loan agreements and corporate governance. ${ }^{51}$ To turn down part of the creditors' claims without requiring the abdication of the shareholders is at odds with the principles of risk and return in investments.

\section{Repurchase of Bonds}

Another practice adopted to combat the bonds' free fall in the market and the imminent risk of default that controlling shareholders have used since the onset of the current crisis is the repurchase of bonds in the market at their updated, discounted, market price. ${ }^{52}$ Bondholders who

50. See, e.g., Michael Rochvarger \& Etti Aflalo, Steinmetz Tries to Give his BSG Bondholders a Steep Haircut, HAARETZ, Dec. 15, 2008, http://www.haaretz.com/hasen/spages/1046523.html (describing Steinmetz' attempt to provide BSG investors with a lower return than their original investment).

51. See, e.g., Etti Aflalo, Ocif Backs Down from Giving Bondholders a Haircut, HAARETZ, Jan. 7, 2009, http://www.haaretz.com/hasen/pages/ShArt.jhtml?itemNo=1053443 (describing how one company backed down from giving bondholders a haircut and instead agreed to a "trim" and paying the investors a higher sum).

52. The repurchases were through the open market. Another potential alternative for debt repurchase is via a tender offer. See Timothy Kruse, Tom Nohel \& Steven K. Todd, The Decision to Repurchase Debt (Mar. 2009), available at http://papers.ssrn.com/sol3/papers.cfm?abstract_id=1364846 (compiling a sample of debt tender offers executed between 1989 and 1996). For adverse effects of such initiatives on bondholders' rights, see John C. Coffee, Jr. \& William A. Klein, Bondholder Coercion: The Problem of Constrained Choice in Debt Tender Offers and Recapitalizations, 58 U. CHI. L. REV. 1207 (1991); Victor Brudney, Corporate Bondholders and Debtor Opportunism: In Bad Times and Good, 105 Harv. L. ReV. 1821 (1992). 
wished to cut their losses and avoid further declines in their portfolios disposed of their bonds and were glad to meet purchasers in the market, regardless of their identity. According to the ISA's data, in the six months between December 2008 and May 2009, 1,715 repurchase transactions took place, relating to 239 series of bonds that were issued by 161 corporations. $^{53}$ The repurchases generated to the selling bondholders an aggregate amount of $\$ 0.475$ billion dollars, on bonds the par value of which was $\$ 0.975$ billion dollars, representing an average discount of $52 \%{ }^{54}$ Approximately $57 \%$ of the repurchases were completed by the controlling shareholder, usually a parent corporation, or a subsidiary of the issuing corporation; $43 \%$ of the repurchases were completed by the issuing corporation itself. ${ }^{55}$ Since real estate corporations are the ones who suffered the most from the bonds crisis, ${ }^{56}$ it is no surprise that approximately $56 \%$ of the aggregate repurchases of bonds in the market were in connection with this industry. ${ }^{57}$

\section{B. Governmental Financial Initiatives}

Several governmental agencies proposed various channels of assistance to deal with the current crisis. Five channels are worth mentioning: (a) the establishment and enlargement of governmentsupported funds for advancing credit to SMEs; (b) a government guarantee for raising additional capital by the banks; (c) a government insurance of new issues of corporate bonds; (d) the establishment of lever funds; and (e) government financing of prepackaged reorganization plans. Channels (a), (b), and (d) were adopted and actually launched, while channels (c) and (e) were not carried forward. Each of the channels is described summarily below.

\section{Credit Funds for SMEs}

Prior to the current crisis, the government, through the Ministry of

53. ISA, Economic Department, The 2007/2009 Credit Crisis, The Corporate Bonds

Market-Self Repurchases 2 (2009), available at http://www.isa.gov.il/Download/IsaFile_3964.pdf(Hebrew).

54. Id. In the year 2008, the volume of repurchases was even greater and totaled $\$ 0.775$ billion dollars. TASE, Research Department, Repurchases of Corporate Bonds in 2008 (2009), available at http://www.tase.co.il/NR/rdonlyres/6B1292EA-1CCD-4D4F-80E4117093ED9E58/0/Research_2009_04_143659.pdf (Hebrew).

55. ISA, supra note 53, at 4; TASE, supra note 54, Graph 1.

56. See supra Part II.B.1. (discussing the effect of the global crisis on Israeli real estate corporations that manage large commercial real estate development projects).

57. ISA, supra note 53, at 5; TASE, supra note 54, Graph 2. 
Finance (MOF), in a joint venture with three medium sized banks, maintained a fund for advancing credit to small businesses, who experienced difficulties in obtaining credit from the banks. One-sixth of the fund is financed by the MOF and five-sixths by the participating banks. The fund advances credit to eligible small businesses and the government provides collateral for $70 \%$ of the amount of each specific loan. ${ }^{58}$ This allows small businesses to obtain financing at reasonable rates while limiting the collateral they would be required to provide to a maximum of $30 \%$ of the loan. During the current crisis, the MOF offered to enlarge the fund by injecting an additional $\$ 10$ million dollars on its part and an additional $\$ 50$ million dollars from the banks. ${ }^{59}$ Eventually this fund received a fresh infusion of $\$ 110$ million dollars from its participants.

In addition, in January 2009, the MOF established a new fund for advancing loans to eligible medium sized businesses, ${ }^{60}$ as a joint venture with participating banks. The fund raised $\$ 325$ million dollars, 20\% of which came from the MOF; participating banks contributed the remaining 80\%. ${ }^{61}$ Any eligible business may obtain a loan from this fund that shall not exceed $8 \%$ of the business' annual turnover. Other terms of the fund include: 1) the annual interest rate shall not exceed the prime rate $+2.9 \%$; 2) the maximum term of the loan is five years; and 3) the government provides collateral for $70 \%$ of the amount of each specific loan. ${ }^{62}$

Recently, the MOF has expressed some dissatisfaction with the low extent of bank lending to the business sector. As a result, the MOF began exploring the possibility of establishing a joint venture with institutional investors' joint funds that will raise $\$ 250$ million dollars in order to provide non-bank credit to private corporations. The primary beneficiaries of these funds would be corporations whose primary assets are intellectual property

58. Eligible businesses for this fund are businesses whose annual turnover does not exceed \$5.5 million dollars.

59. Press Release, Ministry of Finance, The Acceleration Plan is Under Way-The MOF Contacted the Banks for Enlarging the Loans for Small Businesses Fund by 240 Million Shekels (Dec. 10, 2008), available at http://www.mof.gov.il/Lists/List19/Attachments/10/2008-2628.doc. (Hebrew).

60 . Eligible businesses for this fund are those with annual turnover rates between $\$ 5.5$ million dollars and \$25 million dollars.

61. Press Release, Ministry of Finance, Within the Framework of the Acceleration Plan-The Loans for Medium Sized Businesses Governmental Fund in the Amount of 1.3 Billion Shekels has been Launched (Jan. 9, 2009), available at http://www.mof.gov.il/Lists/List19/Attachments/14/2009-12.doc. (Hebrew).

62. Press Release, Ministry of Finance, The MOF Continues to Implement the Acceleration Plan-Contacted Today the Banks for the Establishment of the Loans for Medium Sized Businesses Fund that is Projected to Reach the Amount of Approximately 1 Billion Shekels (Dec. 14, 2008), available at http://www.mof.gov.il/Lists/List19/Attachments/11/2008-2638.doc (Hebrew). 
and corporations in the agricultural industry. ${ }^{63}$

\section{Guaranteeing the Banks’ Raising of Capital}

In a somewhat similar manner to other countries, the Israeli government wished to stabilize the banking industry, given its large role in the credit market and out of concern for the public's deposits. For that purpose, the government provided a $\$ 1.5$ billion dollars guarantee for raising fresh subordinated debt by the banks. ${ }^{64}$ This money is expected to further stabilize the banks and allow them to extend credit to the business sector without risking the exhaustion of the banks' capital surplus and pushing it to the limits of Basel II.

\section{Insurance of Issues of New Bonds}

The Chair of the ISA, Professor Zohar Goshen, proposed that the government provide insurance to the issuing of new bonds in the following manner. ${ }^{65}$ First, the government would sponsor a mechanism that would operate for four years. Newly issued bonds by eligible firms would be placed in a general portfolio, and the institutional investors would invest and purchase units in the collective portfolio. Eighty percent of the aggregate value of the bonds in the portfolio would be insured by the government. In exchange, all issuing firms, participating in the portfolio, would pay a premium to the government or share with it their profits at the end of the four year period. Eligible firms would be those with main operations in Israel. ${ }^{66}$ Firms, whose bonds are included in the government insured portfolio, would be subject to limitations concerning the distribution of dividends, executive compensation and self-dealings between the firms and their controlling shareholders.

63. Etti Aflalo, MOF Is Not Satisfied with the Lending Provided by the Banks-Will Establish New Investment Funds of 1 Billion Shekels, THEMARKer, Aug. 5, 2009, http://www.themarker.com/tmc/article.jhtml?ElementId=skira20090805_1105208 (Hebrew).

64. Press Release, Ministry of Finance, The MOF Provided the Banking System a 6 Billion Shekel Government Guarantee for Raising Capital (Jan. 19, 2009), available at http://www.mof.gov.il/Lists/List19/Attachments/15/2009-72.doc (Hebrew).

65. ISA, News and Publications, Professor Zohar Goshen, Chair of the ISA: Controlling Shareholders Should Realize that Part of the Corporation No Longer Belongs to Them (Apr. 2, 2009), http://www.isa.gov.il/Default.aspx ?Site $=$ MAIN\&ID=8,175,3257 (last visited May 19, 2009) (Hebrew).

66. In addition, holding firms would be ineligible for this proposal. 


\section{Lever Funds}

The MOF initiated the creation of Lever Funds. These funds are funds in which the government invests an aggregate amount of $\$ 1.2$ billion dollars (approximately $\$ 50-\$ 60$ million per fund), and the institutional investors lever the fund by a significant investment on their part. The fund shall incorporate as a limited partnership with the manager of the fund investing at least $1 \%$ of its total capital investments and serving as its unlimited partner and the government and institutional investors holding interests in the fund as limited partners. ${ }^{67}$

Lever funds shall invest their money in eligible firms ${ }^{68}$ for a single purpose: to recycle corporate bonds and finance voluntary arrangements between the firms and their bondholders. ${ }^{69}$ Distributions to the partners in the fund shall be made pro rata. However, in order to encourage the institutional investors to participate in the funds, the government shall assume most of the losses upon the funds' liquidations and limit its part in the liquidation distribution in the event there is a surplus. ${ }^{70}$

The first fund of this sort was launched in March 2009 and raised \$0.5 billion dollars. ${ }^{71}$ In late April 2009, two additional groups were on the verge of winning bids to manage additional funds. ${ }^{72}$ However, as of August 2009 only ten corporations explored the possibility of obtaining financing from the lever funds. Presumably this is because the bonds

67. MOF, Lever Funds - A Joint Private-Government Investment (2009), available at http://www.mof.gov.il/Lists/List17/Attachments/9/manof2008.pps (Hebrew).

68. Eligible firms are firms that (a) issued corporate bonds; (b) are not banks, issuers of financial instruments or government controlled corporations; (c) have at least $50 \%$ of their income (excluding financing income) generated in Israel and $50 \%$ of their assets located in Israel; and (d) the aggregate value of their holdings in securities of other firms does not exceed $50 \%$ of the value of their total assets. Id. at slide 15 .

69. The ISA emphasized that while the lever funds were founded for recycling the existing debt of the firms, the primary goal of the ISA's insurance for the bonds issuing plan was aimed at stimulating the bonds market and regaining the investors' confidence in the capital market.

70. Upon liquidation, in case of a deficit, the government shall pay the institutional investors the lower of $90 \%$ of a $4 \%$ return on their investment or the total distributions the government had previously received from the fund. In case of a surplus that exceeds $4 \%$, the government shall limit its part in the distribution to the mean of the actual return and 4\%. MOF, supra note 67, at slides 21-22.

71. Etti Aflalo, The Breishit Group Won the Tender for Managing the First Lever Fund, THEMARKER, $\quad$ Mar. 10, 2009, http://www.themarker.com/tmc/article.jhtml?log=tag\&ElementId=eaf20090310_87678 (Hebrew).

72. Etti Aflalo, Gabby Tarabelsi's Group Raised the Requisite Minimum for Founding a Lever Fund, THEMARKER, Apr. 2009, http://www.themarker.com/tmc/article.jhtml?log=tag\&ElementId=eaf20090427_37878 (Hebrew). 
market is beginning to show some positive signs of recovery. ${ }^{73}$

\section{Government Financing of Reorganization Workouts}

The Official Receiver proposed a plan as follows: ${ }^{74}$ Within a designated period of two months, any small or medium sized firm which feels it is facing financial distress may apply for a governmental loan to pay off its current debt. A general moratorium shall be statutorily imposed for this designated period. An applying firm shall submit a general business plan to the recommending committee, outlining its general plans for reorganization. All applications will be reviewed by ad hoc committees comprised of lawyers, economists and accountants with adequate background in insolvency. These committees shall recommend to a steering committee, whose members shall be representatives of the Official Receiver, the MOF, the ISA and the General Federation of Labor, the amount of loan that should be provided to each firm and outline the terms that the firm must comply with for being eligible for the loan. The steering committee will allocate among the various applying firms a relative portion of a total sum the government shall set for assistance to all firms, based on priority criteria set by the committee. In exchange, the government shall receive first priority as a creditor of the firm. In addition, the firm shall amend its bylaws and issue a golden share to the government, which shall entitle the government to replace its management should the firm fail to meet the projected goals in its plan within specified time periods. This plan obviates the need to initiate official reorganization proceedings in court.

\section{Government Legal Initiatives: Credit Officers}

Aside from proposals for financial support by the government, the ISA, as the government agency regulating the disclosure of information by securities issuing firms, has attempted to promulgate emergency rules that may facilitate consensual workouts between the issuing firms and their bondholders. The primary legal obstacles that the parties must overcome are: (a) the strict disclosure rules of securities law that mandate public disclosure of any material development, which hinders the quiet and confidential negotiations between the parties; (b) informal communication between parties regarding a possible reorganization plan that may implicate the bondholders in the use of inside information; and (c) the possibility that

73. Most notable among these ten corporations is the real estate giant Africa-Israel. See also Aflalo, supra note 63 (discussing efforts by the MOF to establish new investment funds in order to provide non-bank credit to private corporations).

74. This proposal has been submitted to the Minister of Finance in the Official Receiver's letter of April 20, 2009 and is on file with the author. 
coordination between the institutional investors regarding their position as creditors vis-à-vis the firm may violate antitrust law. ${ }^{75}$

To assist the parties to overcome the aforementioned legal obstacles the ISA adopted a resolution establishing the function of bondholders' committees and credit officers. ${ }^{76}$ This resolution allows an indenture trustee to appoint a bondholders' committee for any series of issued and outstanding bonds. The committee shall be comprised of representatives of the three largest bondholders of that series. The bondholder's committee may appoint a credit officer who shall serve as its representative. The creditor officer may engage in quiet and informal negotiations with the firm regarding a restructuring of the bondholders' rights. The credit officer shall report to the bondholders' committee, consult with it and update it with respect to all the developments in the negotiations with the firm. The appointment of a bondholders' committee and of a credit officer, as well as information obtained by the creditor officer from the firm and reported to the bondholders' committee, shall be exempt from disclosure as an immediate report under the standard rules of securities laws. Also, the mere introduction by the firm of undisclosed information to the credit officer and the bondholders' committee shall not subject the disclosing persons to liability for violation of the prohibition against the use of inside information, to the extent that the disclosing person has no reasonable ground to assume that the recipients of this information shall use it and trade on it. $^{77}$

The Antitrust Authority has complemented the ISA by promulgating an ad-hoc rule for 2009, under which communication and cooperation

75. Aside from overcoming the impediments to reaching a consensual arrangement between an issuing firm and its bondholders, the ISA concluded that in order to lower the probability of similar future crises the protection of bondholders' rights should be fortified through legislation and regulation. It found that the indenture trustees have thus far performed relatively poorly in protecting the bondholders' rights because of the trustees' dependence on the issuing firm. As a result, in June 2009 the ISA released a draft bill amending the Securities Act and its rules, so that they empower the indenture trustees with wider authorities and subject the trustees to the superiority of the bondholders' meeting and to explicit statutory fiduciary duties. Draft Bill and Rules pertaining to Bonds (June 1, 2009), available at http://www.isa.gov.il/Download/IsaFile_3618.pdf (last visited July 20, 2009) (Hebrew). An analysis of the current operation of indenture trustees in Israel and the proposed amendments is beyond the scope of this article.

76. ISA, Plenary Resolution, Resolution re Corporations No. 2009-1(a) - Creating an Infrastructure for Forming Debt Arrangements for Bondholders in Filing Corporations (Nov. 25th, 2008), available at http://www.isa.gov.il/Download/IsaFile_3420.pdf (last visited May 20, 2009) (Hebrew).

77. On June 1, 2009 the ISA released for the public's comments a draft of a bill amending the Securities Act that would vest the authority of the credit officer and the bondholders' committee in the indenture trustee. ISA, Draft Bill and Rules Pertaining to Certificates of Obligation, available at http://www.isa.gov.il/Download/IsaFile_3618.pdf (last visited on June 30, 2009) (Hebrew). 
between members of a bondholders' committee with respect to the modification of the payment terms of the bonds shall not constitute an anticompetitive measure in violation of antitrust laws. ${ }^{78}$

\section{LOW USE OF REORGANIZATION PROCEEDINGS}

\section{A. Empirical Data}

One interesting phenomenon in the current bonds crisis is the relatively low use of formal bankruptcy proceedings in the attempts to resolve specific financial difficulties of bond issuing firms. Based on official filings with the ISA, as of May 2009 only twenty-eight issuing firms have commenced some form of negotiation, workout or official reorganization in order to approve a plan (or arrangement) between the corporation and its bondholders. ${ }^{79}$ Of these reporting firms, four firms were at the time of negotiations in liquidation, two were in official reorganization in court, and twenty-two were negotiating out of court. ${ }^{80}$ In the case of eleven of the reporting firms the parties have eventually filed a motion with the court under Section 350 of the Companies Act, ${ }^{81}$ seeking the official approval of their plan in creditors' meetings and confirmation by the court. ${ }^{82}$ Twelve of these firms were real estate corporations. ${ }^{83}$ In thirteen of these cases the plans included delay of payments or specifying

78. Antitrust Authority, Release 1/08-Cooperation between Institutional Investors in the Modification of Terms in Corporate Bonds (Nov. 25, 2008), available at http://archive.antitrust.gov.il/files/9675/1-08.pdf (last visited on May 20, 2009) (Hebrew).

79. ISA, Economic Department, The 2007/2009 Credit Crisis, The Corporate Bonds Market-Self Repurchases, 3, available at http://www.isa.gov.il/Download/IsaFile_3963.pdf (last visited on July 20, 2009) (Hebrew). As of July 2009, the total of firms negotiating an arrangement has increased to 36. Merav Arlozorov, Debt Arrangements Erased Two Thirds of the Investors' Money, THEMARKER, July 20, 2009 at 62 (Hebrew).

80. From an informal inquiry with the ISA I have learned that only in the case of two firms have the parties employed the ISA's new credit officer scheme.

81. Section 350 of the Companies Act is the general provision of this Act, which facilitates any compromise or arrangement between a corporation and its shareholders or creditors, regardless of the corporation's financial state. To the extent the firm is ailing financially and is seeking temporary relief from its creditors' collection rights, it may file, under section 350(b) of this Act, a motion for a moratorium against the creditors. Cases where the court has ordered a moratorium are regarded as official reorganization cases. Accordingly, the eleven cases where section 350 has been utilized include the two official reorganization cases.

82. ISA, supra note 79, at 11. An alternative mechanism for a majoritarian approval of the modification of the bondholders' rights, as specified in the indenture, is through a bondholders' vote on such a modification under section 35G of the Securities Act.

83. Id. 
installment payments; in eight cases the plans designated collateral to secure the bondholders' rights; in seven cases the plans provided for the issuing of new equity to the bondholders; and in four cases the plans called for an infusion of fresh capital by the shareholders. ${ }^{84}$

It appears that both the distressed firms and their bondholders prefer to avoid a formal bankruptcy resolution. ${ }^{85}$ Bankruptcy is widely regarded as a means of last resort. The following paragraph offers several possible reasons for the seldom use of formal reorganization proceedings to resolve the financial distress of issuing firms.

\section{B. Reasons for Avoiding Reorganization}

Several factors may affect, separately or cumulatively, a firm's decision-makers and its creditors to not use formal reorganization proceedings or at the very least to try to postpone adoption of these proceedings as long as possible. These factors are: (a) the loss of control shareholders and management experience in reorganization; (b) uncertainty concerning the actual rules of Israel's reorganization law; (c) covenant light bonds pose a filing obstacle; (d) a general preference of quiet and consensual workouts; (e) a traditional, cultural, aversion to bankruptcy with its associated negative stigma; and (f) underestimation of the judiciary's competence to handle sophisticated financial matters. These factors are discussed in detail below.

\section{Shareholders' and Management's Loss of Control}

The most likely candidate to file a bankruptcy petition is the debtor. The debtor enjoys superior access to the accurate data concerning its own financial state. Thus, it may move for legal action at the earliest possible stage, when a reorganization of the firm is still a viable option. ${ }^{86}$ Indeed, in

84. Id. at 12. Some of the plans contain a combination of several of the above listed treatments.

85. The total number of firms entering negotiations leading to a reorganization plan, within bankruptcy or outside thereof (twenty-eight, as of May 2009) is less than 18\% of the number of firms that employed bonds repurchases to balance the decline in their bonds' market value and the looming financial distress it signaled (161 firms). The number of firms that entered formal bankruptcy (six, as of May 2009) is less than $4 \%$ of the number of firms repurchasing their bonds. See supra text accompanying note 53.

86. In the case of a corporate debtor the legal action for salvaging the firm is initiated primarily by the board of directors. See Brian M. Hunt \& Rish Handa, A Critical Comparison between Australian and Canadian Creditor Protection Regimes: Voluntary Administration and CCAA 9, n.41 (June 2005), available at $h t t p: / / s s r n . c o m / a b s t r a c t=888411$ (showing the benefits of each country's regime and how they can benefit from one another's experiences). 
practice most reorganization cases are initiated by debtors. ${ }^{87}$ However, upon the initiation of a formal insolvency proceeding, the courts appoint a trustee to control and manage the debtor's property and business affairs. ${ }^{88}$ In a liquidation case, the appointment is explicitly provided by the statute. In reorganization, while not mandated by the legislature, the courts have nonetheless implemented the practice of appointing a trustee to a firm undergoing reorganization. ${ }^{89}$ The trustee displaces the reigning management and board of directors and takes over the business of the firm with a primary goal of maximizing the payments for the creditors. The change of personnel at the helm resonates through the corporate investors. Shareholders, and especially the controlling shareholders, lose control of the firm's business and their influence evaporates almost instantaneously. The new sheriff in town, that is, the trustee, takes orders from and reports to the court, in the name of the creditors. It owes no favors to the shareholders and acts accordingly.

As has been documented and proven empirically, the loss of control upon initiation of formal insolvency proceedings discourages the management from filing. For the classic decision makers in a firm, the managers and the board of directors, their disposition upon the filing makes such proceedings a course of last resort. Indeed, no person volunteers to vacate her seat in favor of a newcomer. Entrenchment, to the extent possible, is more likely. This impedes the probability of a successful reorganization. $^{90}$ Alongside the management stand the controlling shareholders who fear for their control over the firm and, as a result, push the management to hold and delay any filing for a formal insolvency proceeding. ${ }^{91}$ Thus, as long as the relevant financial crisis has not led the creditors to seriously consider filing for liquidation or receivership, firms in

87. This is indeed the case in the U.S. Stuart C. Gilson, Creating Value through CORPORATE RESTRUCTURING: CASE STUdies IN BANKRUPTCY, BUyOUTS, AND BREAKUPS 23, Exhibit I1.1 (2001); Ethan S. Bernstein, All's Fair in Love, War \& Bankruptcy? Corporate Governance Implications of CEO Turnover in Financial Distress, 11 STAN. J. L. Bus. \& FIN. 298, 299, n.3 (2006); Kenneth Ayotte \& Edward R. Morrison, Creditor Control and Conflict in Chapter 1130 Tbl.3 (Columbia Univ. Ctr. for Law \& Econ. Studies, Paper No. 321, 2008), available at http://ssrn.com/abstract $=1081661$.

88. Companies Ordinance (New Version) § 300 (1983) (Isr.).

89. Subsequently, the regulator provided for the appointment of a trustee in reorganization. Rule 14 of the Companies Rules (Application for Compromise or Arrangement) 2002.

90. This has been documented empirically in Barry E. Adler, Vedran Capkun \& Lawrence A. Weiss, Theory and Evidence on the Bankruptcy Initiation Problem (September 2005), available at http://ssrn.com/abstract $=795987$.

91. Arturo Bris, Ivo Welch \& Ning Zhu, The Costs of Bankruptcy: Chapter 7 Liquidation v. Chapter 11 Reorganization, 61 J. Fin. 1253 (2006). The delay in initiation is exacerbated when the concentrated ownership is complemented by a large secured claim. William J. Donoher, To File or Not To File? Systemic Incentives, Corporate Control, and the Bankruptcy Decision, 30 J. MAN. 239 (2004). 
Israel rarely initiate formal reorganization proceedings. It is an unfriendly option for the incumbent decision makers. As a result, this alternative for resolving financial crises is pushed away even if, objectively, it may be the appropriate tool for salvaging the firm.

\section{The Uncertain State of Israel’s Insolvency Law}

In Israel, a financially distressed firm can choose between two main bankruptcy proceedings. The firm can either enter liquidation or reorganization. A distressed firm may also be subjected to receivership by one or more of its secured creditors. ${ }^{92}$ Liquidation proceedings are specified in the Companies Ordinance. The ordinance sets forth many of the traditional aspects that characterize insolvency cases, namely: a stay of all outstanding proceedings against the debtor, ${ }^{93}$ appointment of a trustee to the debtor's property, filing of proofs of claims, avoidance of precommencement preferences, and orderly distribution of the proceeds of the debtor's property among its creditors based on the absolute priority rule. The reorganization statute is more limited in scope. It basically covers only two aspects of the reorganization proceedings. First, it provides for a moratorium on all proceedings against the debtor or its property. Unlike in liquidation, this moratorium suspends the collection rights of all creditors, including the secured ones. ${ }^{94}$ Secondly, the statute authorizes the court to convene a creditors' meeting to vote on a proposed arrangement or settlement. $^{95}$ Originally, this statute addressed only the procedural aspect of allowing the creditors' or shareholders' meetings to approve a proposed arrangement or settlement with a corporation. It was not related to financial distress. Such arrangements were a means to modify existing rights vis-à-vis the corporation whenever changing business circumstances required such modifications. To advance reorganization initiatives and block individual grab of corporate property by a creditor that would frustrate any reorganization plan, however, the statute was hastily amended in 1995 authorizing the courts to impose a general moratorium once a proposal for an arrangement or a settlement has been submitted. ${ }^{96}$

92. Receivership is subject to the Execution Act. A creditor secured by a floating charge may file a motion for the appointment of a receiver under section 194 of the Companies Ordinance.

93. The stay does not preclude secured creditors from foreclosing on their collateral. Thus, the initiation of a liquidation case notwithstanding, secured creditors may separately continue or initiate receivership proceedings for collection of their secured claims. Bankruptcy Ordinance $\S 20$ (b), which has been applied to corporate liquidations in CA 5821/92 Houri v. Fischler, [1996] IsrSC 49(5) 833.

94. Companies Act § 350(b), (f).

95. Id. § 350(a).

96. For a general account of the legislative history of Israel's reorganization law, see 
The important contribution of the statutory moratorium notwithstanding, the current reorganization legislation in Israel remains deficient. The statute currently fails to address many operational and financial issues. Three notable issues that the legislature is yet to address are: (a) the extension of security interests to property acquired within the reorganization case; (b) the state of executory contracts in reorganization; and (c) the confirmation of a reorganization plan over the objection of a class of creditors.

\section{a. Collateralizing Reorganization-Acquired Property}

In Israel, like in the UK, creditors may secure their claim against a corporation by taking a floating charge in all its present and future acquired assets. This security interest is most common among bank lenders. If the loan documents include a contractual provision that limits the corporation from subjecting any of its property to subsequent security interests without advance consent of the creditor secured by the floating charge, and this provision is among the details of the charge filed by the companies registrar, the floating charge gains priority over any subsequent claims, secured and unsecured alike, ${ }^{97}$ except for a purchase money security interest. ${ }^{98}$ The reorganization statute is silent with respect to the question whether newly acquired property during the reorganization proceedings is subject to a pre-reorganization floating charge or not. ${ }^{99}$ Thus, it is unclear whether a potential lender, who has been asked and is contemplating advancing credit to finance a firm's operations while undergoing reorganization can enjoy the priority of a senior security interest in any of the firm's assets free and clear of the floating charge. The Supreme Court has addressed this matter only twice, and reached unclear conclusions. In the first case, the Court assumed, without discussing the matter in depth, that the floating charge extends to post-filing acquired property. Based on this premise, it held that a new lender enjoys priority over the floating charge but only with respect to any existing going-concern surplus value in the property. The creditor secured by the floating charge enjoys seniority in the property's liquidation value, as of the date of filing. ${ }^{100}$ Nonetheless, in a later case the court held that the floating charge ranked lower than the

David Hahn, The Formative Decade of Israel's Reorganization Law: 1995-2004, 14 INT'L INSOLVENCY REV. 121 (2005).

97. Companies Ordinance (New Version) § 169(b) (1983) (Isr.).

98. Id. § 169(d).

99. In the U.S., except for proceedings of the original collateral, property newly acquired in bankruptcy is free from prepetition security interests. BANKRUPTCY CODE, 11 U.S.C. § 552 (2006)

100. CA 6418/93 MAT Investment Corp. v. The Receiver of Carmel Carpets [1995] IsrSC 49(2) 685. 
claim of contractors who were owed payment for completing the construction of a real estate project during the reorganization proceedings of the debtor firm. ${ }^{101}$ The court did not elaborate whether this priority was limited to the going-concern surplus of the project. This unclear state of the law is puzzling for unsecured bondholders as well. To the extent the bondholders are asked to consider the delay of payments in exchange for receiving a security interest in property of the debtor, the apparently unlimited scope of the floating charge becomes a serious hurdle the parties must overcome. Case law has not contributed to any clarity here.

\section{b. Executory Contracts}

A major tool of bankruptcy law that facilitates reorganization is the ability of a trustee, subject to the approval of the court, to assume or reject executory contracts to which the debtor is a party. ${ }^{102}$ Various executory contracts may be of essential importance for the debtor's business. A favorable lease or real property, a license to use certain intellectual property or an uncompleted construction contract, are small examples of strategically important contracts for the continuation of a firm's business as a going-concern. Any interruption of the flow of the business as a result of the termination of such a contract may, under the dire circumstances, cause irreparable damage to the firm's business operations. Thus, continuation of existing executory contracts is of extreme practical importance to a reorganizing firm. ${ }^{103}$

Israeli law addresses primarily a trustee's power to reject an executory contract in liquidation. ${ }^{104}$ The reorganization statute contains no similar provision. More importantly, a trustee's power to assume an executory contract, and if so, under what terms, is left unanswered by the legislature. As a result, courts have been reluctant to allow trustees to assume executory contracts in circumstances where the contract has been breached prior to the commencement of the formal insolvency case and, invariably,

101. CA 7125/00 The Receiver of the Asphalt Group v. Rostom Shalabane [2002] IsrSC 56(3) 507.

102. Executory contract is widely understood as a contract where "the obligations of both parties are so unperformed that the failure of either party to complete performance would constitute a material breach and thus excuse the performance of the other." Griffel $v$. Murphy (In re Wegner), 839 F.2d 533, 536 (9th Cir. 1988). This builds on the definition initially suggested by Countryman. Vern Countryman, Executory Contracts in Bankruptcy: Part 1, 57 MinN. L. ReV. 439, 460 (1973).

103. George G. Triantis, Termination Rights in Bankruptcy: The Story of Stephen Perlman v. Catapult Entertainment, Inc., in BANKRUPTCY LAW STORIES 55 (Robert K. Rasmussen ed., 2007).

104. Companies Ordinance (New Version) §§ 360-65 (1983) (Isr.). 
respect the non-breaching party's right to rescind the contract. ${ }^{105}$ Thus, the future of contracts that were breached because of the debtor's inability to pay as a result of its financial distress, is completely dependent on the good will of the non-breaching party to overlook the breach. Similarly, absent any statutory limitation to the contrary, the courts enforce insolvency ipso facto termination clauses. ${ }^{106}$ Given the wide practice of including such clauses in business contracts, the prospect of assuming executory contracts and preserving the going-concern value they generate is meager. The risk of losing important executory contracts is thus another concern that deters the corporate management and their creditors from turning to formal bankruptcy proceedings.

\section{c. Inter-Class Holdouts}

To approve a proposed reorganization plan the creditors must convene and vote on its terms. For this purpose, the creditors are classified into separate meetings. Creditors sharing homogeneous interests are classified together. ${ }^{107}$ Within each class the proposed plan must achieve a requisite majority. ${ }^{108}$ The problem arises though when one or more of the classes voted against the plan. This creates a challenge as it impedes the practical ability to confirm the plan. This problem is exacerbated as the number of classes increases, thereby also increasing the risk of holdout. ${ }^{109}$ By requiring the unanimous consent of all voting classes, Israel fails to provide workable tools for the confirmation of reorganization plans in circumstances of inter-class disagreements or conflicts of interests.

105. See, e.g., Bankr. (TA) 2166/03, Motion 22204/03 Chuhodruglu Aluminum v. The Interim Liquidator of Hiram Gat [2004] (unpublished opinion).

106. See, e.g., Motion 6483/97 In re Home Mart [1997] (unpublished opinion).

107. This is the general rule for meetings of shareholders or creditors under section 350 of the Companies Act. See CA 70/92 Clal Indus. v. Leumi Pia [1993] IsrSC 47(2) 329 (holding that shareholders holding both Class A and Class B voting stock should be classified separately from the rest of the Class B shareholders); CA 332/88 Bank Leumi v. The Receiver of Kochav Hashomron [1990] IsrSC 44(1) 254 (holding that all secured creditors can be classified together, except Bank Leumi who was the beneficiary of a personal guarantee and thus differed in its economic interests from the other secured creditors). But see BANKRUPTCY CODE, 11 U.S.C. § 1122(a) (2006) (“[A] plan may place a claim or an interest in a particular class only if such claim or interest is substantially similar to the other claims or interests of such class.”).

108. Under section 350(i) of the Companies Act the requisite majority is a majority in person of the actually voting creditors, sans abstainers, who hold $75 \%$ or more of the claims voted in the meeting.

109. Any increase of the total number of individuals whose personal consent is required for approving a proposed decision exacerbates the cost of holdout. Lloyd Cohen, Holdouts and Freeriders, 20 J. LEGAL STUD. 351 (1991). 


\section{Covenant Light Bonds}

Management and shareholders wish to delay for as long as possible the filing for reorganization of their firm in order not to lose their control. Consequently, the task of filing for formal proceedings is one left for the creditors. Yet, in the current bonds crisis, bondholders of some firms suddenly discovered that despite the financial deterioration of the issuing firm their legal options are limited. The debenture, under the terms of which their bonds were issued, lacks common financial covenants that demand the maintaining of certain financial ratios and provide that failure to oblige constitutes an event of default and acceleration of their entire claim. ${ }^{110}$ As discussed earlier, the issuing of commercial bonds in Israel is a relatively young practice. Preliminary negotiations between issuing firms and the indenture trustee (on behalf of the investors) on the terms of the offered bonds were yet to be perfected. Occasionally, the latter have not insisted on the inclusion of contractual clauses commonly found in private loan agreements. ${ }^{111}$ As a result, as long as the issuing firm has not yet reached a date of payment of interest to the bondholders, the latter were in no legal position to declare a default by the firm. Subsequently, the path to initiating formal bankruptcy proceedings appeared blocked for the time being.

\section{Preference of Unofficial Workouts}

Regardless of the legal details and mechanisms of formal insolvency proceedings, bondholders are generally reluctant to enter these proceedings. Their general preference is to negotiate with the issuing firm quietly and informally in search of a consensual restructuring for the terms of the bonds. ${ }^{112}$ The out of court workout has been further facilitated by the

110. The phenomenon of covenant-light loans is common practice even in sophisticated and developed financial markets like the U.S. The leniency there was, inter alia, a result of the desire of managers of hedge funds and private equity to close as many deals as possible and get paid their bonuses as a result thereof. Harvey R. Miller, Chapter 11 in TransitionFrom Boom to Bust and into the Future, 81 Am. BANKR. L.J. 375, 380-83 (2007).

111. A recent study of the financing of LBOs between 2001 to 2006 confirms that covenant-light loans were typical for loans originated by institutional investors and were accompanied with higher interest spreads. Joseph R. Mason, Wei-Ling Song \& Jerry Cao, Business Aggression, Institutional Loans, and Credit Crisis: Evidence from Lending Practices in Leveraged Buyouts 3 (2009), available at http://papers.ssrn.com/sol3/papers.cfm?abstract_id=1362421. See also Adam Gallagher, Covenant Lite: The High-Water Mark of the LBO Market?, 26-6 AM. BANKR. INST. J. 30 (2007) (discussing how the American financing trend of covenant lite leveraged loans has hit Europe resulting in several "covenant lite" senior financing deals in the European market).

112. For empirical data on out of court workouts compared to formal bankruptcy 
ISA in its adoption of the credit officer mechanism. ${ }^{113}$ The bondholders feel that they may reach their goals without the need to utilize official reorganization proceedings. The official reorganization proceedings may nonetheless be used by the parties, in a prepackaged format, upon reaching a consensual path. In order to simplify the confirmation of the negotiated solution and have it bind all dissenting creditors, the parties may seek the voting rules and court approval provided for under section 350 of the Companies Act (the section that also constitutes the reorganization statute. $)^{114}$ This use of section 350 of the Companies Act is essentially a prepackaged reorganization proceeding. ${ }^{115}$

As for the risks of unilateral filings for reorganization by the issuing firms, the institutional investors count on their leverage as repeat players to reliably threaten the issuing firms from taking any such measures. ${ }^{116}$ Given that these investors are well organized and primary holders of corporate bonds in the Israeli market, ${ }^{117}$ the issuing firms will likely hesitate to upset the institutional investors and waste their good standing therewith. Any subsequent debt financing will backfire against the issuing firm, as it will be required to raise the interest rate on that debt instrument. The firms are thus wary of unilaterally initiating a formal reorganization proceeding and risking the ire of the institutional investors. ${ }^{118}$

\section{Cultural Rubicon}

Another reason for the aversion of formal reorganization proceedings is a cultural barrier. The Israeli business world regards formal insolvency

proceedings, see supra Part IV.A.

113. See supra Part III.C (discussing how the ISA resolution established the function of bondholders' committees and credit officers).

114. See supra Part IV.A (empirical data on the use of section 350 for concluding the negotiations).

115. John McConnell \& Henri Servaes, The Economics of Pre-packaged Bankruptcy, in Corporate BANKruptcy: ECONOMiC AND Legal Perspectives 322 (Jagdeep S. Bhandari \& Lawrence A. Weiss eds., 1996); Douglas G. Baird \& Robert K. Rasmussen, Chapter 11 at Twilight, 56 STAN. L. REV. 673, 679 (2003).

116. Neil Gunningham, Private Ordering, Self-Regulation and Future Markets: A Comparative Study of Informal Social Control, 13 L. \& Policy 297 (1991).

117. For the segmentation of the holdings of corporate bonds in Israel, see supra note 25.

118. But see John C. Coffee, Jr. \& William A. Klein, Bondholder Coercion: The Problem of Constrained Choice in Debt Tender Offers and Recapitalizations, 58 U. CHI. L. REV. 1207 (1991) (discussing the coercive forces that may lead bondholders, including institutional investors, to accept haircuts and other informal workouts proposed by a distressed issuing firm, when the firm's management may reliably threaten to file for bankruptcy). The concern raised by Coffee \& Klein is strong in the U.S. because managers are less averse from turning to bankruptcy. See supra Part IV.B.1 (discussing how the loss of control upon initiation of formal insolvency proceedings often discourages Israeli management from filing for bankruptcy). 
proceedings as a plague. Investors, controlling shareholders, accounting firms and creditors alike feel that entering a formal proceeding is always, under any circumstances, the last resort and the least desired alternative. ${ }^{119}$ In their eyes, the initiation of a formal insolvency proceeding itself is destructive. The formal proceedings can do no good for the firm. The very initiation of such proceedings is official evidence that the firm is insolvent and that its viability as a going-concern is questionable. ${ }^{120}$ The filing for bankruptcy will only exacerbate the firm's delicate standing vis-à-vis its suppliers, employees and customers, many of whom will seek doing business elsewhere. ${ }^{121}$ This dramatic event in the life of a firm marks the beginning of its end. The general understanding is that any formal bankruptcy case is the ultimate failure of a debtor. Correspondingly, the market reaction to an announcement that a formal insolvency proceeding has been commenced is a steep drop in the valuation of the firm's securities and a further loss to the investors. Thus, it is widely believed and accepted among the creditors that the longer formal proceedings can be avoided, the better. Accordingly, in the recent bonds crisis, the bondholders preferred any alternative - a consensual out-of-court workout with the firm or an ad-hoc governmental bailout plan — over formal bankruptcy proceedings. In short, no one wishes to come near bankruptcy because it is considered an illegitimate option for a functioning business. ${ }^{122}$

This approach, although widely accepted and relied upon in practice, represents a culturally erroneous perception of bankruptcy and its essence. The popular approach, even shared by many lawyers, is that the initiation of bankruptcy is the drawing of a line between two periods in the life of a debtor firm. Before the commencement of the proceedings the firm may have been ailing but, nonetheless, an operating business. Upon the filing

119. See Amir Helmer, How to Reorganize a Failing Real Estate Corporation (Oct. 10, 2004) available http://www.haaretz.com/hasite/pages/ShArtPE.jhtml?itemNo=486280\&contrassID $=2 \&$ sub ContrassID $=10 \& s b S u b C o n t r a s s I D=0$ (Hebrew) (debtors file with the courts petitions for formal bankruptcy proceedings only after the banks make it clear to the controlling shareholders that the business can no longer be run as usual).

120. In the Globes-PWC joint research, the only two alternatives of action for bondholders analyzed were an out of court workout or formal liquidation. GLOBES Researches \& PriceWATERHOUSECOOPERs, supra note 40, at 2223. This indicates that even the most sophisticated and respectable accounting firms in Israel fail to fully comprehend the legal option of formal reorganization and its positive potential.

121. Id. at 22 .

122. The current general resentment of insolvency proceedings in Israel is reminiscent of the public atmosphere in the U.S. in the 1960s. See Miller, supra note 110, at 376 ("[I]n the 1960s, bankruptcy was a small, arcane, undesired practice area. After the Second World War, the volume of bankruptcies and particularly old Chapter XI cases was very minor. Credit was relatively tight. Major law firms and accounting firms shunned the area of bankruptcy. The stigma of bankruptcy was very much to be avoided.”) 
for bankruptcy, the firm loses its good standing as it publicly proclaims its failure. Unfortunately, this approach overlooks the detailed legal mechanism of bankruptcy and the fundamental values it is intended to promote. Regardless of the legal functions of bankruptcy proceedings and its virtues, in the business world, much like the consumer context, the term "bankruptcy" connotes failure and financial disaster. ${ }^{123}$ The roots for this popular view may be historic and may have lost legal ground over the years. ${ }^{124}$ Nonetheless, in the eyes of a layperson, bankruptcy is a predicament one should avoid. ${ }^{125}$ Because the business world has not changed its traditional hostility and suspicion towards bankruptcy, any firm and its creditors who wish to resolve the firm's financial difficulties successfully, should distance the firm from such proceedings. Thus far, this popular attitude, regardless of its merit, has indeed kept the bondholders away from the bankruptcy courts.

\section{Underestimation of the Courts' Competence}

The parties involved in the bonds crisis, debtors and creditors alike, generally display skepticism regarding the courts' competence to handle acute economic matters and reach optimal decisions. ${ }^{126}$ The general concern is that judges who lack expertise in evaluating firms, analyzing their financial statements, and dissecting their periodical performances will be called upon to decide the overall fate of such firms. ${ }^{127}$ Any initiation of

123. Teresa A. Sullivan, Elizabeth Warren \& Jay L. Westbrook, Less Stigma or More Financial Distress: An Empirical Analysis of the Extraordinary Increase in Bankruptcy Filings, 59 STAN. L. REV. 213 (2006).

124. For the influence of moral norms on the social psychology pertaining to bankruptcy, see Gordon Bermant, Bankruptcy by the Numbers: What's Stigma Got to Do with It?, 22-6 AM. BANKR. INST. J. 22 (2003).

125. American non-legal professionals exhibit a similar misunderstanding of Chapter 11 and its virtues. The (erroneous) general belief among non-legal persons is that the filing for Chapter 11 doomed Lehman Brothers and that major distressed businesses should stay away from bankruptcy as long as they can. Stephen J. Lubben, Systemic Risk \& Chapter 11, 82 Temple L. Rev. 433 (2009). See also Horacio Spector, Don't Cry for me Argentina: Economic Crises and the Restructuring of Financial Property, 14 FORDHAM J. CORP. \& Fin. L. 771 (2009) (arguing that a bankruptcy paradigm can maintain a separation of powers, reduce rent-seeking by small interest groups, and mitigate the overall damage to the financial system caused by the economic crisis).

126. See, e.g., Michael R. Baye \& Joshua D. Wright, Is Antitrust Too Complicated for Generalist Judges? The Impact of Economic Complexity \& Judicial Training on Appeals (George Mason Law \& Econ. Research Paper No. 09-07, 2008), available at http://papers.ssrn.com/sol3/papers.cfm?abstract_id=1319888 (concluding that there is support for the hypothesis that some antitrust cases are too complicated for generalist judges).

127. This concern is found worldwide. See, e.g., Alan Bancaud \& Anne Boigeol, A New Judge for a New System of Economic Justice, in PROFESSIONAL COMPETITION AND Professional Power 104 (Yves Dezalay \& David Sugarman eds. 1995) (discussing the 
formal insolvency proceedings moves the court to the front, and vests in the judge the authority to make all the critical calls, whether operational, investment or financing. ${ }^{128}$ The business parties resent the thought of a court running the business de facto and perceive this alternative inferior to others. ${ }^{129}$ Obviously, the preferred method for resolving their financial issues is through a consensual negotiated plan of payment. ${ }^{130}$ Yet, the second best alternative in the eyes of the market is a government brokered plan, such as the establishment of lever funds or guaranteeing the value of newly issued bonds whose proceeds will retire the outstanding debt on the old (and payable) bonds. The common denominator of these plans is that they are orchestrated and planned to be managed or supervised by branches of the government. These plans are traceable to the Ministry of Finance. The common view is that the persons behind the designing of these plans and their execution are ranking officers in the Ministry of Finance, whose economic grasp is far superior to that of any judge in the judicial system. The MOF employs some of the brighter economic minds in Israel's market. Thus, any financial crisis that the major firms are experiencing would likely be treated more efficiently by the MOF or the ISA and their staffs than by the courts. Also, the government addresses the crisis from a macro point of view, while courts always focus on the specific case at hand and miss the larger picture of the economy as a whole. Thus, a systemic bailout program launched by the government is perceived a preferable alternative to a case by case attempt to salvage the ailing firms and the investment of the bondholders (and directly of all the public who invest their long term

change that has occurred in the position and the role of the French Judiciary). See also Patricia M. Wald, Judicial Review of Economic Analyses, 1 YALE J. REG. 43 (1983) (discussing how judicial review of economic analyses is an increasingly important task for American federal appellate courts, which requires judges to understand often arcane economic issues, and providing some suggestions for how to approach mixed issues of law and economics).

128. In enacting chapter 11 of the U.S. Bankruptcy Code Congress' original intention was actually to relegate the bankruptcy courts to the role of mere adjudicators of controversies while leaving the operational aspects of the case to the professional parties. In practice, however, this intent has not worked out. See Harvey R. Miller, The Changing Face of Chapter 11: A Reemergence of the Bankruptcy Judge as Producer, Director, and Sometimes Star of the Reorganization Passion Play, 69 AM. BANKR. L. J. 431 (1995) (describing the active roles bankruptcy judges play in Chapter 11 proceedings).

129. For a refute of the rhetoric emphasizing the judges' lack of expertise, see Edward K. Cheng, The Myth of the Generalist Judge, 61 Stan. L. Rev. 519 (2008). However, recent experimental studies cast doubts whether specialized judicial experience bears added value for calculated decision making. Jeffrey J. Rachlinski, Chris Guthrie \& Andrew J. Wistrich, Inside the Bankruptcy Judge's Mind, 86 B.U. L. REV. 1227, 1230 (2006); Chris Guthrie, Jeffrey J. Rachlinski \& Andrew J. Wistrich, The "Hidden Judiciary": An Empirical Examination of Executive Branch Justice, 58 DUKE L. J. 1477 (2009).

130. Globes Researches \& PriceWaterhouseCoopers, supra note 40. 
savings in funds managed by the institutional investors). ${ }^{131}$

A testament to both the cultural barrier and the underestimation of the courts' competence is the Official Receiver's initiative for a government financing of reorganization workouts. ${ }^{132}$ The parameters of the Official Receiver's proposal effectively emulate main elements of a formal reorganization proceeding (moratorium, priority financing), but without the actual resort to the court's jurisdiction. This proposal is a surrogate to the path the Official Receiver understands that the parties wish to avoid.

\section{THE BENEFITS AND COSTS OF GOVERNMENT INTERVENTION}

The preceding part outlined various explanations for the avoidance of formal insolvency proceedings by firms and their bondholders. These explanations may be summarized under two general categories: legal reasons and extra-legal reasons. The legal reasons include the uncertainty of the current state of insolvency law in Israel and the personal cost for managements and controlling shareholders once official proceedings have commenced. The extra legal reasons include the general expectation for a wide scale governmental intervention in the crisis, a cultural aversion from the stigma of bankruptcy, and holding face by the institutional investors who fear that setting a precedent of writing off significant debt while allowing the survival of their debtor firm will saddle them in future cases.

All parties were well aware that paying off the bonds of many firms was practically impossible and thus some modifications must have been made. The question then was what type of modifications and whose supervision would best serve the firms and their creditors. Should the government launch an ad-hoc plan for backing the firms or is a case-bycase approach through bankruptcy proceedings preferable? I believe there is no solution that is clearly and convincingly superior to all others. This part will outline the relative advantages and costs of each approach. Given the positive potential of both channels the following part will recommend certain improvements and a change of attitude so that firms and their creditors can benefit from the relative advantages of a (case-by-case) bankruptcy resolution for the firms' financial distress. ${ }^{133}$

131. For a similar general understanding in the U.S. concerning the treatment of the systemic financial crisis, see Kenneth Ayotte \& David A. Skeel, Bankruptcy or Bailouts? (U

Penn. Inst. Law \& Econ., Research Paper No. 09-11, 2009), available at http://ssrn.com/abstract=1362639.

132. See supra Part III.B.5 (discussing the Official Receiver's proposal in detail).

133. See also Bastian Breitenfellner \& Niklas Wagner, Government Intervention in Response to the Subprime Financial Crisis: The Good into the Pot, the Bad into the Crop (Feb. 2009), available at http://papers.ssrn.com/sol3/papers.cfm?abstract_id=1334804 (cautioning against a wide scale substitution of bankruptcy resolution for financial distress by government sponsored rescue packages). 


\section{A. The Advantages of Government Intervention}

All variations of government intervention across the border to rescue ailing firms from defaulting on their issued and payable bonds enjoy certain advantages over the resolution of the crisis through the bankruptcy judicial system. These advantages are: (a) the presence and involvement of a strong and able financial guarantor; (b) reduction in administrative costs due to streamlining of payable corporate debt; (c) an inter-firm consistent treatment of creditors; (d) a quick implementation of the rescue initiative; and (e) the move is likely to stimulate the economy.

\section{Governmental Financial Backing}

Governmental financial support, either through an insurance of new bonds issues or through subsidized funds that infuse fresh capital to the distressed firms,alleviates the firms' burdensome debt. The government's support lowers the firms' cost of capital and allows them to continue their operations undisturbed. ${ }^{134}$ In contrast, when a firm resorts to court supervised bankruptcy, as a practical matter, it must obtain financing from a financial lender. The availability of such financing during a general financial crisis is limited. Also, such financing is more expensive than the government's subsidy. ${ }^{135}$

\section{Saving Administrative Costs}

A wide scope government intervention spares the firm and its creditors the need to litigate the specific financial crisis of the firm in court. This removes the need for a particular judicial measurement of the concrete financial position of each firm. Administering a wide-scale crisis on a case-by-case basis clogs the judicial pipeline and increases the administrative costs since it requires retaining the services of lawyers, accountants and financial advisors on behalf of the litigating parties. A government plan for all firms suffering the crisis is a general and unified treatment that bypasses the microscope examination of each particular firm.

134. But see id. (arguing that government financial support for distressed firms should be deliberately supplied at a significant cost to those firms). For a proposal to lower the cost of banks' recapitalization through finance supplied by the private sector, see John C. Coates, IV \& David S. Scharfstein, Lowering the Cost of Bank Recapitalization, 26 YALE J. REG. 373 (2009).

135. On the other hand, the amount of financing a firm would need in a bankruptcy case is smaller because, unlike in the case of governmental support, it needs the cash only for its operations and not for paying off its outstanding debts. Skeel \& Ayotte, supra note 131. 


\section{Inter-Firm Consistent Treatment of Creditors}

A wide scale government plan of relief for distressed firms allows the creditors to enjoy the same treatment and grants them an opportunity to save their sunken investments in a consistent manner. ${ }^{136}$ Many creditors, and particularly institutional investors, invest in bonds of various firms. Such creditors look at their overall portfolio of bonds and measure the returns or losses on the portfolio. The consistent and unified approach afforded by government intervention ensures these creditors the salvation of their investments (and indirectly those of all employees who invest their retirement savings in the institutional investors). In contrast, judicial resolution of financial distress varies across different judges. ${ }^{137}$ Moreover, in treating the creditors' claims on a case-by-case basis the judicial system is prone to error in certain cases and thus decreases the overall return on the public's investments. ${ }^{138}$ Thus, per-crisis in the market, a government plan enjoys the upper hand in its clarity and predictability. ${ }^{139}$

\section{Quick Implementation}

Once adopted formally, a governmental rescue plan may be implemented rather quickly. Either the governmental support will apply automatically to any eligible firm or the firm will contact the governmental agency that is in charge of implementing the plan and prove its eligibility. Because a governmental bailout applies evenly to all ailing firms, it is less threatening from a debtor firm's perspective. Such a plan is less stigmatizing than an official judicial bankruptcy proceeding and it does not

136. In contrast, bankruptcy cases are governed on a case-by-case basis, by potentially different judges across the country, which makes it difficult to apply a coordinated reply to a wide scale economic crisis. See Lubben, supra note 125, at 440-41 (" $[T]$ he fractured nature of a series of bankruptcy cases within an industry makes it difficult to implement a coordinated policy response across multiple firms. ...”).

137. See, e.g., Arturo Bris, Ivo Welch, and Ning Zhu, The Costs of Bankruptcy, 61 J. FIN. 1253, 1297 (2006) ("[W]hether unsecured creditors recover more or less seems to relate to which judge is drawn.”).

138. Even where creditors hold a portfolio of bonds the losses of errant judicial decisions in particular cases do not necessarily balance by the positive results generated in the cases adjudicated correctly and effectively, due to a general bias of the judicial system. See Nicola Gennaioli and Stefano Rossi, Judicial Discretion in Corporate Bankruptcy (Jan. 2009), available at http://papers.ssrn.com/sol3/papers.cfm?abstract_id=1051441 ("[J]udicial idiosyncrasies do not average out just like pure noise. . . . Chapter 11 is systematically pro-debtor. ...”).

139. The government's per-crisis intervention is nonetheless susceptible to the costs of ad-hoc legislation when comparing the treatment of creditors in different economic crises. See Part V.B.3 infra (discussing the limits of consensual workouts regulated by credit officers when compared to reorganization proceedings). 
require, per se, any change of control of the firm. ${ }^{140}$ Thus, the timely initiation of the governmental rescue plan appears more promising than the initiation of a judicial bankruptcy proceeding. Moreover, the terms of a governmental rescue are predetermined by the government and are not negotiated with any specific firm. This may expedite the implementation of the plan and eliminate the need for lengthy negotiations between the parties entailed by a formal bankruptcy resolution. ${ }^{141}$

\section{Stimulating the Economy}

A governmental rescue intervention typically draws the full attention of the domestic media. All the players in the capital market rely on the terms of the government's plan and are inspired by it. A wide scale governmental support revives the confidence of investors in the economic activity and reenergizes the capital markets. ${ }^{142}$ In this sense, a constructive contribution of the government's intervention lies in the stimulation of a cash constrained economy. ${ }^{143}$ The panic effect that is exacerbated once an economic crisis escalates to a national level is best squelched by a government pacifier.

\section{B. Costs and Limitations of Intervention}

Part III has shown that the government considered various economic and legal measures of intervention in light of the bonds crisis. A broad brushed financial intervention bears the following costs: (a) it uses taxpayers' money to subsidize losses in the private sector; and (b) it

140. However, a sponsoring government may press for change of personnel at the corporate helm, as was the case recently with GM. Mike Allen \& Josh Gerstein, GM's CEO Resigns at Obama's Behest, POLITICO, March 29' 2009, available at http://www.politico.com/news/stories/0309/20625.html. Unlike in Israel and many other countries, in the U.S. Chapter 11 negates this consideration as it provides for the preservation of the debtor's management as debtor-in-possession. See BANKRUPTCY CODE, 11 U.S.C. § 1107 (2006) (allowing debtor-in-possession to retain management).

141. See Luigi Zingales, Why Paulson is Wrong, in The First Global FinANCIAL CRisis OF THE 21st CENTURY, PART II: JunE-DECEMBER, 2008, 277 (Andrew Felton \& Carmen M. Reinhart eds. 2008) (assuming that Chapter 11 negotiations would take months).

142. See, e.g., Ron Stein \& Eran Peer, The Lever Funds are Under Way: At Least 80\% of Their Money will be Invested Directly in Debt Arrangements, GLOBES, Jan. 1, 2009, available at http://www.globes.co.il/news/article.aspx?did=1000412939 (Hebrew) (the Ministry of Finance is providing fresh credit to the business sector in order to stimulate the economy)

143. But see Luigi Zingales, Plan B, 5(6) The Economists' Voice (Oct. 2008), available at http://www.bepress.com/ev/vol5/iss6/art4 (arguing that the vast majority of the government's rescue money is being used by the rescued financial institutions to pay off their existing debts rather than vitalizing the economy through the supply of fresh financing to the markets). 
amplifies management's moral hazard of risk taking. In addition, the new legal alternative advocated by the ISA, pursuant to which the bonds crisis would be resolved through consensual workouts via the credit officer mechanism, is a poor substitute for formal bankruptcy as it is shorthanded in comparison to bankruptcy. These shortfalls are discussed below.

\section{Use of Taxpayers’ Money}

The most obvious cost of a government bailout is the immediate burden it places on the country's treasury. ${ }^{144}$ Taxpayer money is relied upon to remedy the mistakes of the private sector. ${ }^{145}$ While this current burden may pay off in the future, if and when it stabilizes the economy and reenergizes it, it is nonetheless questionable whether, as a matter of principle and as a philosophical matter, the general public should serve, after the fact, as a general guarantor of players in the private sector. ${ }^{146}$ Moreover, on a practical basis, there is a limit to the amounts the government can allow itself to spend on the rescuing of distressed businesses. ${ }^{147}$

\section{Moral Hazard}

Ken Ayotte and David Skeel are among the latest commentators to elaborate on the moral hazard problem that a governmental bailout would produce. $^{148}$ Ex ante, the expectation for a general bailout in a wide

144. Certain commentators associate this argument politically with the Republican Party. See Howard L. Rosenthal, Letter: Republican Opposition to Debt Reduction in Financial Crises-The Great Depression and Today 5(5) ThE Economists' Voice, (Oct. 2008) available at http://www.bepress.com/ev/vol5/iss5/art12/ (describing Republican party's reaction to government intervention during national financial crises).

145. See Zingales, supra note 141 (describing costs to taxpayers of AIG government bailout).

146. Altman \& Philippon advocate the use of taxpayer's money, through a government DIP loan to GM inside Chapter 11, but only because of the collapse of the DIP-finance market as a result of the general financial crisis. Edward I. Altman \& Thomas Philippon, Where Should the Bailout Stop, in Restoring FinANCIAL STABILITY: How to RePAIR A FAILED System 353 (Viral V. Acharya \& Matthew Richardson eds. 2009).

147. This may explain recent hesitations in the U.S. from bailing out additional faltering firms. See Dean Foust \& Theo Francis, CIT: Not Too Big to Fail, Bus. WK., Jul. 13, 2009, available

http://www.businessweek.com/bwdaily/dnflash/content/jul2009/db20090713_500893.htm

(also citing sources who call for utilizing a prepackaged bankruptcy in lieu of a bailout).

148. Ayotte \& Skeel, supra note 131. The problem discussed in the main text is a debtor's moral hazard problem. In a somewhat different context the International Monetary Fund's sovereign-debt bailouts have raised the concern of investors' moral hazard. See, e.g., Jong-Wha Lee \& Kwanho Shin, IMF Bailouts and Moral Hazard, 27 J. INT'L MonEY \& FIN. 816 (2008) (finding differences between lending spreads and underlying risks 
economic distress encourages managers of the largest firms to overinvest and take excessive risks in belief that eventually the government will not let their firms fall. ${ }^{149}$ Managers and directors of such firms adopt the mantra that their firms are simply "too big to fail." by the managers' modern days' inclination to overly risk the firms' operation in expectation of reaping increased executive compensation calculated on the basis of (shortsighted) high returns. ${ }^{151}$ Moreover, as Ayotte and Skeel argue, ex post the managers and directors may exacerbate the moral hazard problem by deliberately allowing the firm to deteriorate further, in order to paradoxically enhance its chances of receiving the government aid it seeks. ${ }^{152}$ That is, the firm races itself to distress to pass the dubious "poor firm in need of government bailout" threshold. This behavior only worsens the firm's position at a time where quick reconstructive actions of its managers and directors could have righted the ship.

\section{The Limits of Consensual Workouts}

As a legal response to the current bonds crisis the ISA regulated the

consistent with moral hazard caused by expectations of IMF lending). For a historical (and skeptical) account of general bailouts and their adverse effect on managements of the railroad industry, see Joseph R. Mason \& Daniel A. Schiffman, Too Big to Fail, Government Bailouts and Managerial Incentives: The Case of the Reconstruction Finance Corporation Assistance to the Railroad Industry during the Great Depression, in ToO BIG To Fail: Policies and Practices in Government Bailouts 49 (Benton E. Gup ed. 2004) (finding that railroads reduced maintenance, contrary to long-term solvency, when assistance rather than bankruptcy procedures were used).

149. But see Tito Cordella \& Eduardo L. Yeyati, Bank Bailouts: Moral Hazard vs. Value Effect, 12 J. Fin. InTERMEDIATION 300 (2003) (arguing that the risk-reducing value of a central bank bailout outweighs the costs of moral hazard in adverse macroeconomics circumstances). In a similar vein, see also Steven B. Kamin, Identifying the Role of Moral Hazard in International Financial Markets (FRB Int'l Fin. Discussion Paper No. 736, 2002), available at http://papers.ssrn.com/sol3/papers.cfm?abstract_id=333382 (disputing the evidence for moral hazard caused by IMF-led financing packages).

150. For an example of the regulators' dilemma whether to bail out or not, based on this sense, see Peter S. Goodman, Too Big to Fail?, N.Y. TIMES, July 20, 2008, available at http://www.nytimes.com/2008/07/20/weekinreview/20goodman.html?pagewanted $=1 \&$ \& $=1$ (emphasizing that bailouts and massive economic collapse are both contrary to American political ideology); David Henry, Stanley Reed, Cristina Lindblad \& Paula Lehman, Too Big to Fail, Bus. WK., Jan. 24, 2008, available at http://www.businessweek.com/magazine/content/08_05/b4069032985454.htm (highlighting the extreme consequences inherent in either option a central bank can pursue in financial crises).

151. See, e.g., Kevin Dowd, Moral Hazard and the Financial Crisis, (CRIS Discussion Paper Series-2008.VI, 2008), available at http://www.nottingham.ac.uk/business/cris/papers/2008-6.pdf (arguing that moral hazard is fundamental to analyzing bailout policies).

152. Ayotte \& Skeel, supra note 131. 
operation of credit officers. ${ }^{153}$ The wide perception in the market is that this legal arrangement is superior to official reorganization proceedings. The scheme of credit officers facilitates a quiet workout between a firm and its bondholders without resorting to judicial intervention and the disruption of the normal course of the firm's business. Much like any consensual workout, the scheme of credit officers is indeed a constructive contribution to the successful resolution of payment crises in public corporations. However, this scheme and any other form of workout fall short once coordination problems ${ }^{154}$ and conflicts of interest between the bondholders and other creditors, such as bank lenders, or between the bondholders interse abound. ${ }^{155}$ In such circumstances classes of creditors that oppose the proposal negotiated between the firm and (a class of) its bondholders may effectively impede the proposal by asserting their own collection rights. ${ }^{156}$ In such situations, which are common in practice, ${ }^{157}$ the scheme of credit

153. See supra Part III.C (describing the ISA's regulation of credit officers).

154. See Robert Gertner \& David Scharfstein, A Theory of Workouts and the Effects of Reorganization Law, 46 J. FIN. 1189 (1991) (presenting a model highlighting coordination inefficiencies faced by public debtholders during the workout process).

155. On the holdout problem in consensual bondholders' workouts, see Coffee \& Klein, supra note 118, at 1232-42 (illustrating the problems introduced by "vulture funds" in a bondholder workout). In the U.S., the problem of bondholders' holdout is exacerbated because section 316(b) of the Trust Indenture Act, 15 U.S.C. §§ 77aaa-77bbbb, rejects the majoritarian vote and prohibits any modification of the original payment terms of the bonds issued thereunder absent the individual consent of each bondholder. See Mark J. Roe, The Voting Prohibition in Bond Workouts, 97 YALE L.J. 232 (1987) (advocating a repeal of individualized bondholder choice as it contributes to unnecessary bankruptcies); George W. Shuster, Jr., The Trust Indenture Act and International Debt Restructurings, 14 ABI L. REV. 431 (2006) (describing the uncertain place individualized bondholder choice holds in modern debt restructurings). On the coordination problem in workouts between bondholders, see Robert Gertner \& David Scharfstein, A Theory of Workouts and the Effects of Reorganization Law, 46 J. Fin. 1189 (1991) (finding that coordination inefficiencies are not mitigated by feasible means for restructuring public debt).

156. For an empirical support of this argument, see Stuart C. Gilson, Kose John \& Larry H.P. Lang, Troubled Debt Restructurings: An Empirical Study of Private Reorganization of Firms in Default, in BANKRUPTCY \& DisTRESSED RESTRUCTURINGS 77 (Edward I. Altman ed., 1998). For a proposal for facilitating cooperative collective action outside of bankruptcy and overcoming the self-interested private enforcement by individual creditors, see Claire Finkelstein, Note, Financial Distress as a Noncooperative Game: A Proposal for Overcoming Obstacles to Private Workouts, 102 YALE L.J. 2205 (1993) (advising that debt contracts incorporate a clause suspending creditors' state law collection rights for a fixed period of time).

157. See, e.g., Michael Rochwerger, Polishek Holds Enough Cash to Pay Its Bondholders by the End of February - the Banks are Refusing to Release the Cash, THE MARKER, Jan. 2, 2009, available at http://www.themarker.com/tmc/article.jhtml?log=tag\&ElementId=mr20090201_111121 (last visited June 1, 2009) (Hebrew) (the Polishek case exemplifies a conflict of interests between the bondholders and the bank, which threatens to thwart a consensual arrangement). It is a common understanding in the capital market that without the consent of the bank lenders any proposed workout between bondholders is liable to fail. GLOBES 
officers fails to solve the crisis and save the firm. ${ }^{158}$

In addition, bankruptcy equips the parties with the constructive benefits of a wide moratorium. ${ }^{159}$ Thus, while the negotiations between the parties take place, no single creditor whose claim is due and payable may disrupt the negotiations by creating a run at the debtor's assets. The consensual workout alternative does not provide such a safety net and is thus wholly dependent on the good will and restraint of each and every creditor of the debtor. Finally, bankruptcy laws benefit the financers of a distressed debtor by according them a high priority in the order of claims. ${ }^{160}$ No such benefits may be obtained, however, in an out-of-court workout.

\section{THE CASE FOR USING REORGANIZATION LAW}

\section{A. Reorganization Law: The Cure, Not the Plague}

By and large, the Israeli business sector has practically rejected formal bankruptcy proceedings as a mechanism for resolving the financial distress of viable firms and promoting a reorganization plan for the benefit of the firm and its creditors. The popular, yet completely errant, perception is that official bankruptcy proceedings, of any kind, are a death writ for a debtor firm who shall enter such proceedings. The reasons for this perception have been discussed in Part IV. In the previous part, I have shown that alternative mechanisms, like government intervention or out-of-court workouts, are far from being optimal solutions for business financial distress as they suffer from numerous shortcomings. In my eyes, ruling out the use of bankruptcy proceedings for resolving the bonds crisis is erroneous as it unjustifiably narrows the available channels for resolving the crisis and abandons the very mechanism that was designed specifically for such situations.

I believe that all players, the debtor firms, their creditors (institutional

Researches \& PriceWATERHouseCoOPers, supra note 40, at 15, 35-37 (Hebrew).

158. For a proposition that repeat workouts with various issuers decrease the concern of a bondholder holdout, see Royce de R. Barondes, An Economic Analysis of the Potential for Coercion in Consent Solicitations for Bonds, 63 FoRDHAM L. REV. 749 (1994) (demonstrating that, under proper assumptions, issuers are unable to create a Prisoner's Dilemma for bondholder consent solicitations).

159. In Israel, the moratorium is ordered by the court pursuant to section 350(b) of the Companies Act. In the U.S., once a bankruptcy petition has been filed the stay applies automatically under section 362(a) of the Bankruptcy Code.

160. See, e.g., BANKRUPTCY CODE, 11 U.S.C. § 364 (2006) (providing that if the trustee is unable to obtain unsecured credit, the court may authorize the obtaining of credit or the incurring of debt with priority over any or all administrative expenses of the kind specified in other sections of this title). 
and non-institutional alike), the government agencies who regulate the capital market and the Ministry of Finance in its capacity as the treasurer of the taxpayers' money, should realize that there are legal tools designed specifically for resolving the financial distress of debtor firms and facilitating the payment to their creditors, without losing the viability of the firms. Those tools are found in bankruptcy law. Once Israel's law has adopted a reorganization regime, bankruptcy should no longer be treated as a terminal disease that ought to be avoided as long as possible. Quite the contrary is true. Reorganization law was enacted explicitly as a mechanism for rescuing distressed firms and protecting their going-concern value for the benefit of their creditors. A firm who is experiencing a payment crisis can stabilize itself and reach a workable solution with its creditors through the reorganization proceedings. These proceedings often only simplify otherwise complex matters and procedures. ${ }^{161}$ The potential of reorganization proceedings is especially powerful when coupled with a prenegotiated or prepackaged reorganization plan. The creditors and the firm together can enter quiet and relatively peaceful negotiations pertaining to the modified terms of payment, the design and structure of the firm's future capital and its prospective business plan. During these negotiations the debtor continues to run its business, uninterrupted, in its ordinary course. ${ }^{162}$ Once the negotiations are ripe for finalization, the firm can enter bankruptcy and enjoy the automatic stay, new opportunities for financing and the advanced and flexible mechanism of approving the reorganization plan by classes of creditors. ${ }^{163}$ Thus, instead of avoiding bankruptcy law, all actors should embrace it as an available and useful, albeit by no means the sole, vehicle for rescuing firms. For that to happen, the most notable change that is required has to do with perception. The traditional bankruptcy phobia must make way to a modern constructive and unbiased understanding that bankruptcy law is not the terminal move in the game all should avoid as long as possible. ${ }^{164}$ Bankruptcy should not be a measure of

161. For a similar argument concerning the positive role of Chapter 11 for U.S. businesses, see Lubben, supra note 125 (countering criticisms of the inadequacy of Chapter 11 for major institutions in financial distress).

162. Courtney C. Carter, Note, Saving Face in Southeast Asia: The Implementation of Prepackaged Plans of Reorganization in Thailand, Malaysia, and Indonesia, 17 BANK. DEV. J. 295 (2000).

163. However, sometimes a quick bankruptcy case is no more than a reflection of poor bankruptcy practice. For such an argument concerning the case of Chrysler's swift bankruptcy case, see Mark J. Roe \& David A. Skeel, Jr., Assessing the Chrysler Bankruptcy (Aug. 2009), U. Penn. Inst. L. \& Econ. Research Paper No. 09-22, available at http://ssrn.com/abstract=1426530 ("[T]he Chrysler bankruptcy cannot be understood as complying with good bankruptcy practice....”).

164. On the adverse perception of business bankruptcy in the business community, see Robert I. Sutton \& Anita L. Callahan, The Stigma of Bankruptcy: Spoiled Organizational Image and Its Management, 30 Ac. MAN. J. 405 (1987) (proposing that Chapter 11 
last resort used only after all the (so-called) conventional attempts to solve a firm's financial distress have been exhausted. Bankruptcy law is a judicially prescribed treatment of financial distress. A reorganization case should be regarded as an opportunity, not as a black hole. While at the early stage of the case there exists uncertainty regarding the ultimate form of relief for the firm and the treatment of the creditors' claims, the same is true with respect to any negotiations oriented alternative. The ultimate outcome is unknown to the parties beforehand. Any out of court arrangement is similarly vulnerable to break down. ${ }^{165}$

\section{B. The Need for Modern Reorganization Law}

In the past, regional economic crises have led to the reform of national insolvency laws and the legislation of reorganization schemes. Such legislation was intended to set a framework for salvaging domestic businesses. Indeed, crises are traditionally catalysts for improvement and reform. The recent bonds crisis in Israel can, and in my eyes should, be a catalyst for revising its reorganization law. Revising the law and fine tuning it may contribute to a rational business environment that would be willing to use reorganization law wisely and efficiently. To the extent that the revised law will appeal to the parties and present a flexible platform for relieving a cash constrained debtor from the burden of due and payable claims, it is expected to assume its rightful place at the fore of the business legislation and complement its counter parts, namely contracts law, corporate law, securities regulation, and the law of secured transactions. Such a revision would benefit the business world and fill a substantial hole that currently impedes the proper functioning of business entities, their investors and financers.

To make reorganization law appealing and a useful tool, the following revisions should be legislated:

(a) adopting a DIP regime for debtor firms, the control of whom is dispersed;

(b) carving the absolute priority of the floating charge;

(c) facilitating the continuance of executory contracts in general, and license and franchises in particular, during reorganization; and

(d) adopting the cramdown mechanism.

discredits a firm and its managers, causing a series of negative responses that lead to significant organizational trouble).

165. This vulnerability is exacerbated outside of bankruptcy by the lack of a moratorium. Thus, any solo action by a creditor to levy on the firm's property and collect notwithstanding the negotiated workout may turn to be the brick drawn out of the (eventually) collapsing wall. 
As explained above in Part IV.B, the current statutory law is deficient in that it has thus far failed to provide the debtor and its creditors with sufficient incentives to use reorganization and to address their mutual conflicts of interest through mitigating tools. The revisions I propose herein are intended to fill this legislative gap.

\section{Adopting a DIP Regime}

Any debtor enjoys information superiority over its creditors regarding the debtor's financial state. As a result, the debtor is the classic initiator of reorganization actions. ${ }^{166}$ Given the appropriate incentives, a debtor would use its informational advantage to take action for saving its business as early as necessary. In the corporate context it is thus essential to entice the primary decision makers of the debtor, namely its managers and directors, to timely resort to formal reorganization and take advantage of its constructive facets. ${ }^{167}$ A DIP regime is precisely the measure necessary to neutralize the decision makers' aversion to reorganization proceedings. From their perspective, it is control of the firm more than any other factor that drives them away from official proceedings. A proceeding that leaves them at the helm is the antidote for their aversion. Adopting a DIP regime is the most significant legal reform aimed at transforming reorganization from law in the books into law in action.

Given the practical dependency of managers and directors of a firm on the controlling shareholder of that firm, however, a DIP regime would effectively entrench the controlling shareholder at a time when the best interests of the creditors should prevail in the firm's decision making. ${ }^{168}$ Outside formal bankruptcy, in the regular business environment, financial creditors are equipped with sophisticated contractual covenants to combat any externalization of risks created by the controlling shareholder. In

166. This argument is strongly supported by empirical research. See STUART C. GILSON, Creating VAlue through Corporate Restructuring: Case Studies in Bankruptcies, BUYOUTS, AND BREAKUPS Chapter 1 (2001) (presenting corporate restructuring primarily as a challenge of corporate management). See also Kenneth M. Ayotte \& Edward R. Morrison, Creditor Control and Conflict in Chapter 1130 tbl.3 (Columbia Univ. Ctr. for Law \& Econ., Research Paper No. 321 and Northwestern Univ. Law Sch. Law \& Econ. Research Paper Series, Paper No. 08-16, 2008), available at http://ssrn.com/abstract=1081661 (presenting information about corporate bankruptcy cases filed in 2001); Ethan S. Bernstein, All's Fair in Love, War \& Bankruptcy? Corporate Governance Implications of CEO Turnover in Financial Distress, 11 STAN. J.L. Bus. \& FIN. 298, 299 n.3 (2006) (noting the rarity of involuntary bankruptcies in the United States).

167. See Susan Block-Lieb, Why Creditors File So Few Involuntary Petitions and Why the Number is Not Too Small, 57 BroOK. L. Rev. 803, 804-05 (1991) (discussing the tactical advantages conferred upon debtors that voluntarily file for bankruptcy).

168. David Hahn, Concentrated Ownership and Control of Corporate Reorganisations, 4 J. CORP. L. STUD. 117, 131 (2004). 
bankruptcy, however, the contractual enforcement rights of creditors are suspended due to the legal moratorium. Thus, paradoxically, absent tight control by the presiding court, a controlling shareholder may enjoy a more lax business environment inside bankruptcy than outside, jeopardizing the creditors' money within the formal framework. Therefore, converting reorganization law from a trustee-controlled regime to a DIP-controlled regime should be done cautiously and conservatively. I believe that a shift to a DIP regime should be applied at first only with respect to publicly traded firms whose stock is diffuse, with no shareholder holding a controlling position. In such firms, the only decision makers that matter are the managers and directors. Once the decision makers are encouraged to file for bankruptcy, they are also likely to read the map correctly and adopt the creditors' agenda as their own. ${ }^{169}$ In these cases, the shadow of the shareholders is hardly threatening to management. Diffuse stock ownership is typical in large firms, whose financial distress severely affects many other actors and the economy at large. Thus, encouraging these firms to timely file for bankruptcy is expected to be a positive legislative contribution to the successful handling of financial distress.

Another statutory provision that may simplify the reorganization initiation problem described above would be an amendment that would explicitly entitle creditors holding unliquidated or unmatured claims to file for reorganization. ${ }^{170}$ Should such an amendment be enacted, an indenture trustee, on behalf of the bondholders, would be entitled to file for reorganization of the distressed issuing firm once it has defaulted on any of its financial covenants, even if the debenture lacks an acceleration clause. The mere deterioration in the debtor's financial stability, and the heightened risk of default and insolvency as a result thereof, shall suffice for collective actions initiated by the creditors. The fact that the specific payment to the petitioning creditor is not yet due will not weaken that creditor's entitlement to take action aimed at saving the debtor's goingconcern value and preventing stalling tactics by the firm's management and board of directors. ${ }^{171}$ This amendment shall overcome the problem encountered by holders of covenant-light bonds. ${ }^{172}$

169. Id.

170. Cf. BANKRuptcy Code, 11 U.S.C. § 101(5)(A) (2006) (defining the term "claim”), 303(b)(1) (2006) (describing commencement of an involuntary case by holders of claims).

171. Alternatively, the legislature or regulator may demand the inclusion of an acceleration clause in any corporate bonds issuing as a mandatory prerequisite for public offering of the bonds. Such a potential initiative is currently discussed by the regulators. See Ministry of Finance, The Committee for Establishing Parameters for INSTITUTIONAL BODIES' INVESTMENTS IN NONGOVERNMENTAL BONDS-INTERIM REPORT FOR PUBLIC COMMENTS (Sept. 2009), available at http://www.finance.gov.il/hon/2001/hon_dep/memos/chodek-e.pdf.

172. However, the amendment does not overcome creditors' hesitation to initiate a 
Simplifying the conditions for a creditors' initiation of bankruptcy cannot serve as a proxy for a DIP regime, however. As explained above, given its information superiority, the debtor is the ultimate initiator of reorganization proceedings. Additionally, even if initiated by creditors in a timely manner, trustee-controlled bankruptcy suffers from inefficiencies due to the vulnerability of the newly appointed trustee and the confrontational atmosphere in which the trustee functions. ${ }^{173}$ Therefore, an optimal legal regime would provide the firm's decision makers with the proper incentives to file for reorganization, rather than turning the legal attention to creditors' initiated proceedings. Thus, adopting a DIP regime for diffused (shareholder) control firms is the preferable legal reform.

\section{Carve-Out of Floating Charges}

It has been mentioned above that pre-bankruptcy secured creditors, holding an encompassing floating charge on all the debtor firm's assets, enjoy an effective financing monopoly. ${ }^{174}$ No other creditor would voluntarily finance the firm, as it is automatically junior to the holder of the floating charge. This leads to various inefficiencies, including overlending by the holder of the floating charge, ${ }^{175}$ suboptimal monitoring by the fully secured creditor, ${ }^{176}$ and externalization of risks to the other creditors. ${ }^{177}$ In the context of negotiating a reorganization of capital arrangement with a firm's bondholders, this absolute priority of the floating charge over the entire firm's property, including property acquired during the reorganization case, frustrates the ability of the debtor firm to offer the bondholders delayed installment payments secured by a prime security interest in uncollateralized property. To overcome this problem, the legislature should amend the statute to provide that property acquired during the reorganization case is free of any pre-bankruptcy security

collective bankruptcy case, given the adverse effect of free riding by the other creditors. See Douglas G. Baird, The Initiation Problem in Bankruptcy, 11 INT'L REV. L. \& ECON. 223, 223-24 (1991) (discussing the collective action problem that hinders creditors' initiation of bankruptcy proceedings).

173. Hahn, supra note 168 , at 124-27.

174. See David Hahn, When Bankruptcy Meets Antitrust: The Case for Non-cash Auctions in Concentrated Banking Markets, 11 STAN. J.L. Bus. \& FIN. 28, 30 (2005) (explaining that in concentrated banking markets, banks' domination of the supply side of financing creates the potential for a squeeze-out of the debtor's junior creditors in bankruptcy proceedings).

175. David de Meza, Overlending?, 112 Econ. J. F17, F22 (2002).

176. John Hudson, The Case Against Secured Lending, 15 InT'L REV. L. \& ECON. 47, 54 (1995); Alan Schwartz, The Continuing Puzzle of Secured Debt, 37 VAND. L. Rev. 1051, 1057-59 (1984).

177. Lucian Arye Bebchuk \& Jesse M. Fried, The Uneasy Case for the Priority of Secured Claims in Bankruptcy, 105 YALE L.J. 857, 881-82 (1996). 
interests ${ }^{178}$ or alternatively, to carve out a certain percentage from the firm's property that is subject to the floating charge in favor of other creditors. The latter idea was proposed some years ago in the U.S. by Bebchuk and Fried. ${ }^{179}$ Either alternative would facilitate the use of the firm's property in advancing a bondholders' arrangement.

\section{Saving Executory Contracts}

As stated earlier, in Israel the fate of executory contracts upon the filing for reorganization is extremely fragile. Any ipso facto clause may terminate the contract. Also, case law is unclear on the issue of whether a pre-commencement payment default entitles the non-debtor party to rescind the contract. Such contracts may be a license obtained and used by the debtor firm, or a real estate lease in a primary and strategic location. Under current law, the filing for reorganization does not immunize these contracts from rescission, and may even be the official contractual trigger for their termination. ${ }^{180}$ The triggering events of ipso facto clauses cast dark shadows over any formal reorganization initiative. ${ }^{181}$ Wishing to preserve the business' substantial assets, distressed firms that are lessees or licensees attempt to avoid formal bankruptcy as long as possible and resolve their financial problems outside the courtroom. However, given the various obstacles presented outside of formal bankruptcy, namely the lack of moratorium and the consent required from all creditors for any debt restructuring, it may be wise to reverse the legal factors that influence the actions of the parties. By enacting into law the invalidity of ipso facto clauses and facilitating the continuation of previously breached executory contracts, formal reorganization would become a hospitable arena for salvaging financially ailing firms. Executory contracts would continue to run and generate the firm's core business, while the parties enjoy the advantageous rules of reorganization law that facilitate their reaching a consensual reorganization plan. Saving executory contracts would remove

178. Cf. BANKRUPTCY CoDE, 11 U.S.C. § 552(a) (2006) (“[P]roperty acquired by the estate or by the debtor after the commencement of the case is not subject to any lien resulting from any security agreement entered into by the debtor before the commencement of the case.”). Should such a provision be enacted in Israel, it ought to be conditioned upon the safeguard of adequate protection for the rights of the holder of the floating charge in its secured claim.

179. See Bebchuk \& Fried, supra note 177, at 909-11 (discussing the "fixed-fraction priority rule," in which a fixed fraction of the secured creditor's secured claim would continue to be treated as a secured claim, while the remainder would be treated as an unsecured claim).

180. See supra notes 104-06 and accompanying text (discussing legislation and case law relating to executory contracts).

181. Triantis, supra note 103. 
a major tactical component of the decision-makers' aversion to bankruptcy. The veracity of this argument has been proven empirically. ${ }^{182}$ Israel should follow this path if it wishes to perfect its reorganization law.

\section{Cramdown}

The final revision that may enhance the efficacy of formal reorganization would be the enactment of a cramdown provision. That is, the reorganization statute should provide for the confirmation of a reorganization plan over the dissent of one or more of the voting classes of creditors or equity holders. ${ }^{183}$ Given the conflicts of interest among classes in general, and among various series of bonds in particular, the dissent of a certain voting class is a very likely possibility. Enacting a cramdown provision would facilitate reorganization, as it would neutralize the ability of any single class to hold out and veto the plan. This removes one of the major impediments to salvaging the firm and arranging a payment plan for its creditors. Moreover, by allowing the confirmation of a plan over the dissent of a class, the legislature would effectively encourage the various classes to display more flexibility at the bargaining table and reach a consensual arrangement, in order to avoid the deep involvement on the part of the court that would be required in the case of cramdown. ${ }^{184}$ Thus, the legislation of a cramdown provision may eventually prove itself as a catalyst for out-of-court workouts.

\section{IMPLICATIONS FOR THE U.S.}

There is much debate over the appropriate method for addressing widespread financial crises around the globe, both in emerging markets as well as developed and sophisticated ones. The financial crisis of 2009 has compelled the U.S. government to devise a policy and select an approach for dealing with the crippled financial sector. Realizing the severe ramifications of non-intervention, the government chose to open its treasury and provide financial institutions on the brink of insolvency with unprecedented amounts of cash. This policy effectively follows the idea of firms that are simply "too big to fail." ${ }^{\text {"185 }}$ The public sector refuses to let go

182. Simeon Djankov, Oliver Hart, Caralee McLiesh \& Andrei Shleifer, Debt Enforcement around the World, 116 J. POL. ECON. 1105 (2008).

183. The U.S. cramdown provision is located in BANKRUPTCY CODE, 11 U.S.C. § 1129(b) (2006).

184. See Douglas G. Baird \& Donald S. Bernstein, Absolute Priority, Valuation Uncertainty, and the Reorganization Bargain, 115 YALE L.J. 1930, 1952-63 (2006) (discussing the bargaining process that takes place during corporate reorganizations).

185. See supra note 150 and accompanying text (discussing the concept "too big to 
and allow the private sector, as troubled as its state may be, to independently sort out its predicament. The government was not willing to allow the investors in the financial markets to bear all the losses from the mismanagement of their investments. The billions of dollars lost in the crisis, the snowball effect on the entire economy and the loss of trust in the market system-one of the foundations of the U.S. economy-outweighed all counter-considerations and drove the government to carry the load and bail out the failing firms.

At first, this intervention policy of the U.S. government was praised by commentators. However, after a while, many began voicing counterarguments doubting the wisdom of this policy. ${ }^{186}$ Whether any firm or sector is indeed "too big to fail," and thus justifies a subsidy from the taxpayers, is the subject of heated debate and will not be resolved any time soon. ${ }^{187}$ Most notably, Ken Ayotte and David Skeel have highlighted the costs and adverse effects of a government bailout. ${ }^{188}$ In their article, Ayotte and Skeel argue that the moral hazard exacerbated by the bailout is likely to taint future transactions in the market and encourage managers to overinvest. $^{189}$ Thus, the disciplinary power of the market may be lost precisely because of the bailout. ${ }^{190}$

The lesson to be learned from Israel's struggle with the fall of its bonds market in 2009 may support Ayotte and Skeel's proposition. Despite the initial national concern for a widespread loss of the public's long-term pension savings, the Israeli Government eventually chose not to intervene, and instead opted to withhold its reserves, forcing all the relevant market players to resolve their financial crises on their own. ${ }^{191}$ The events

fail”).

186. For example, Joseph Stiglitz advocates government financing of troubled firms in exchange for preferred stock of those firms. Joseph E. Stiglitz, We Aren't Done Yet: Comments on the Financial Crises and Bailout, 5 THE ECONOMISTS' VoicE, Issue 5, Article 11 (2008).

187. For criticism of the treasury's generous use of taxpayers' money, see Aaron S. Edlin, Questioning the Treasury's \$700 Billion Blank Check: An Open Letter to Secretary Paulson, 5 The ECONOMISTS’ VoICE, Issue 5, Article 4 (2008).

188. Ayotte \& Skeel, supra note 131.

189. Id. at 20-21. See also Manfredo A. Dix, Letter, The Dangers of Forgetting Moral Hazard, 5 The Economists' Voice, Issue 5, Article 15 (2008) (discussing the moral hazard of bailing out the subprime mortgage borrowers).

190. See David O. Beim, Good Bailouts and Bad, 5 The Economists' Voice, Issue 5, Article 8 (2008) (arguing that bad bailouts only worsen the functioning of the market); Luigi Zingales, Yes We Can, Secretary Geithner, 6 The Economists' Voice, Issue 2, Article 3 (2009) (discussing that the market reaction to the Troubled Asset Relief Program revealed that government intervention essentially transferred wealth from taxpayers to financial investors).

191. Adrian Filut, Minister of Finance, Steinitz: We Shall Not Intervene in Cases of Bonds Defaults, GLOBES, Aug. 31, 2009, available at http://www.globes.co.il/news/articleaspx?did=1000494123\&fid=585 (Hebrew) (discussing 
that have transpired since illustrate that once all actors realize that there is no realistic chance to extract subsidies from the government for paying the private sector's debts, negotiations will progress more effectively and the parties will somehow configure a solution to best suit their situation. ${ }^{192}$ These solutions are far from ideal. Indeed, in many cases, the dealings are with an insolvent debtor and the eventual return to the creditors is far from being whole. Nonetheless, through these private solutions, the parties prove that even large financial losses may be borne by the private sector without necessarily crippling the entire economy. While the market suffers a temporary fall, its overall integrity may be preserved. Future investments will be made with greater caution and will be coupled with insistence on enhanced transparency and improved monitoring of managers' investment decisions.

The previous parts of this paper showed that the solutions devised in the Israeli market were reached under sub-optimal conditions. Avoiding the use of formal bankruptcy proceedings may impair the debtor's value and hamper the parties' bargaining positions. The primary reasons for this avoidance, namely the divestment of management and controlling shareholders of their control, the vagueness of the statutory law and the negative connotation of formal reorganization proceedings, are less prevalent in the U.S. The Bankruptcy Code is far more developed and sophisticated than Israel's insolvency law, is debtor-friendly and is more acceptable as a means for resolving corporate financial distress. These factors make the U.S. a more workable and accommodating arena for resolving the financial crisis than its counterparts around the globe. Thus, the lesson from Israel's recent experience, which proves that government abstention from aiding failing firms does not necessarily cripple the market but rather drives its actors to act on their own, may suggest that the nonintervention policy is even more promising for the U.S. The advantages of U.S. bankruptcy law should be utilized for resolving financial distress of market giants. The alternative bailout is simply too costly, both in the present (the use of taxpayers' money) and in the future (moral hazard). ${ }^{193}$

the government's refusal to intervene in assisting Africa-Israel Investments and other corporations in paying its debts).

192. The actual consensual workouts in the two largest financial crises in Israel, those of the real estate giant Africa-Israel and of the shipping corporation Zim, are direct results of the government's announced policy.

193. Yet, realistically, this suggestion may be qualified. To the extent that a crisis hits the financial sector across the board, the severe danger of a colossal meltdown of the entire financial system may at times outweigh the costs of subsidizing the market with taxpayers' money and moral hazard and justify certain governmental intervention. Cordella \& Yeyati, supra note 149. 


\section{CONCLUSION}

The global economic crisis of 2008-2009 has affected many emerging markets and slowed down their business activity. Israel is no exception. Many firms have recently faced financial distress and were struggling to keep their payment obligations and avoid default. The novel aspect of the crisis is the wide exposure of holders of listed and traded bonds to default. Investors in the young Israeli bonds market treated these investments as solid and safe ones, only to discover during the crisis that they were subject to substantial losses resulting from the looming insolvency of the issuing firms. A large percentage of the bonds is held by institutional investors, which manage the long-term savings of the public. This has created public interest in the search for satisfactory solutions to the bonds crisis.

Several government bailout proposals have been considered. However, the eventual official announcement of the Minister of Finance that the government will not bail out even the largest firms from the private sector has put these initiatives to rest. ${ }^{194}$ Thus, the parties were necessarily drawn back to the negotiations table. Nonetheless, and perhaps surprisingly, the path of formal reorganization proceedings under bankruptcy law has been largely overlooked, if not deliberately and consciously avoided. Dodging reorganization may be explained as the result of several cumulative factors. One major factor contributing to this situation is a general misconception of the constructive role reorganization law plays in salvaging ailing businesses. This misconception may be remedied only through a consistent and gradual cultural change towards understanding insolvency and what its law represents. Another major factor is the poor state of Israeli reorganization law. Several aspects of current reorganization law deter the decision makers in a firm, as well as their creditors, from utilizing this channel.

This paper calls for using the crisis as a catalyst for reforming Israel's reorganization law, strengthening its weak aspects and transforming it into an attractive, practical and workable channel for the satisfactory resolution of creditors' rights and the rescue of viable businesses.

194. See Filut, supra note 191 (reporting the Minister of Finance's statement that the government has decided to refuse bailing out financially distressed corporations). 